\title{
New complexes of chelating Schiff base: Synthesis, spectral investigation, antimicrobial, and thermal behavior studies
}

\author{
Basim Hatim Al-Zaidi*, Mohammed Mujbel Hasson, Ahmad Hussein Ismail \\ Department of Chemistry, College of Science, Mustansiriyah University, Baghdad, Iraq.
}

\begin{tabular}{|c|c|}
\hline ARTICLE INFO & ABSTRACT \\
\hline Received on: 07/09/2018 & The new bidentate Schiff base ligand (E)-1-(4-((E)-(4-(diethylamino)-2-hydroxybenzylidene)amino)phenyl)ethanone \\
\hline Accepted on: 22/01/2019 & oxime HL has been synthesized via condensation of equal amounts of 1-(4-aminophenyl)ethanone oxime and \\
\hline Available online: $18 / 04 / 2019$ & $\begin{array}{l}\text { 4-Diethylaminosalicylaldehyde. The title ligand characterized by using (IR, UV-Vis) spectroscopies, }\left({ }^{1} \mathrm{H},{ }^{13} \mathrm{C}\right) \mathrm{NMR} \\
\text { spectra, mass spectrum, and X-ray crystallography. Chelated complexes of the prepared ligand with } \mathrm{Co}(\mathrm{II}), \mathrm{Ni}(\mathrm{II}) \text {, }\end{array}$ \\
\hline $\begin{array}{l}\text { Key words: } \\
\text { N,O-bidentate Schiff } \\
\text { base complexes, } \\
\text { antibacterial, antifungal, } \\
\text { p-aminoacetophenone oxime, } \\
\text { TG/DTG/DTA-analysis, } \\
\text { X-ray crystallography. }\end{array}$ & $\begin{array}{l}\text { and } \mathrm{Cu}(\mathrm{II}) \text { ions have been also prepared with a ratio of } 1: 2, \mathrm{M}: \mathrm{L} \text {, and characterized by (IR, UV-Vis) spectroscopies, } \\
\text { magnetic susceptibility, molar conductivity, and flame atomic absorption measurements. Results of spectral studies } \\
\text { proved the chelation behavior of this ligand, which coordinated to metal ions as a monobasic N,O bidentate ligand, via } \\
\text { imine and phenolic oxygen atom, after losing its proton. Tetrahedral geometry has been proposed for Co(II) complex } \\
\text { and square planar geometry has been proposed for } \mathrm{Ni}(\mathrm{II}) \text { and } \mathrm{Cu}(\mathrm{II}) \text { complexes, respectively. The analysis studies of } \\
\mathrm{TG} \text { /DTG/DTA data reflected potential and good thermal stability of HL and its metal complexes. We also obtained } \\
\text { the biological activity of the prepared compounds against two Gram-positive bacteria (Staphylococcus aureus and } \\
\text { Staphylococcus epidermidis), four Gram-negative bacteria (Salmonella, Escherichia coli, Pseudomonas aeruginosa, } \\
\text { and Klebsiella spp.), and one fungus (Candida albicans). }\end{array}$ \\
\hline
\end{tabular}

\section{INTRODUCTION}

Bidentate Schiff-bases ligands and complexes derived from salicylaldehyde and its derivatives characterized by the existence and participation of azomethine group and the hydroxyl group after losing its proton in coordination with metal ions (Elena et al., 2015). The chelated complexes of these organic compounds have potential and important applications in different scientific fields. It also used in a biological field as anti-fungal, anti-bacterial, anti-oxidant, and anticancer drugs (Elena et al., 2015; Hui et al., 2017; Kumar et al., 2018; Senbagam et al., 2016). In an analytical field, some of the Schiff bases derived from salicylaldehyde or its derivatives have been used in extraction (Swati and Uma, 2016) and spectrophotometric determination (Duong et al., 2011) of

"Corresponding Author

Basim Hatim Al-Zaidi, Department of Chemistry, College of Science, Mustansiriyah University, Baghdad, Iraq.

E-mail: basimhatim@uomustansiriyah.edu.iq metal ions. Bidentate chelated complexes have noticeable stability and thermal degradation behaviors (Ratiram et al., 2013a; 2016).

\section{EXPERIMENTAL}

\section{Materials and measurements}

Reagents and solvents obtained from commercial sources were used as received without any further purification. FTIR spectra of prepared compounds were recorded by a Shimadzu (FT-IR) model 4800S spectrophotometer in the range of $4,000-400 \mathrm{~cm}^{-1}$ by using $\mathrm{KBr}$-discs. The single crystal X-ray diffractometer SMART Apex 2 100K, Bruker has been used to obtain X-ray structure of ligand HL. The UV-Visible spectra of prepared compounds were recorded by using a UV-Visible spectrophotometer type Cary $100 \mathrm{con}$. in the range of 800-200 $\mathrm{nm}$. A Stuart melting point (digital) SMP30 apparatus recorded melting points of prepared compounds. MS analysis of prepared ligand was performed on GC-MS QP-2010 (Shimadzu). ${ }^{1} \mathrm{H}$ and ${ }^{13} \mathrm{C}$ NMR spectra of precursor and ligand were recorded in DMSO- $\mathrm{d}_{6}$ by using a Bruker DMX-500 spectrophotometer ( $300 \mathrm{MHz})$. The percentages of metal ions were determined by using a novAA350 


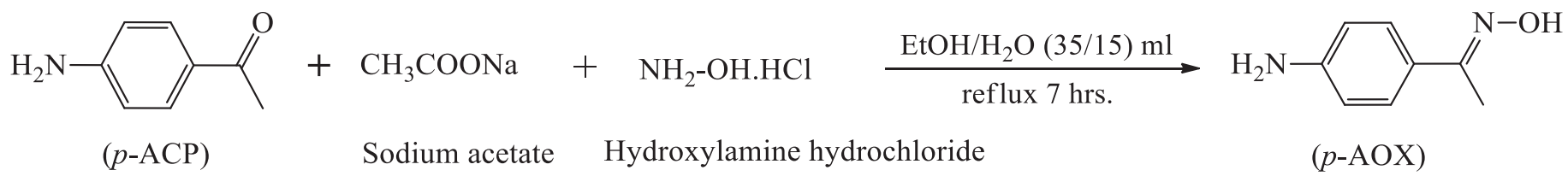

Scheme 1. Preparation reaction of ( $p$-AOX).
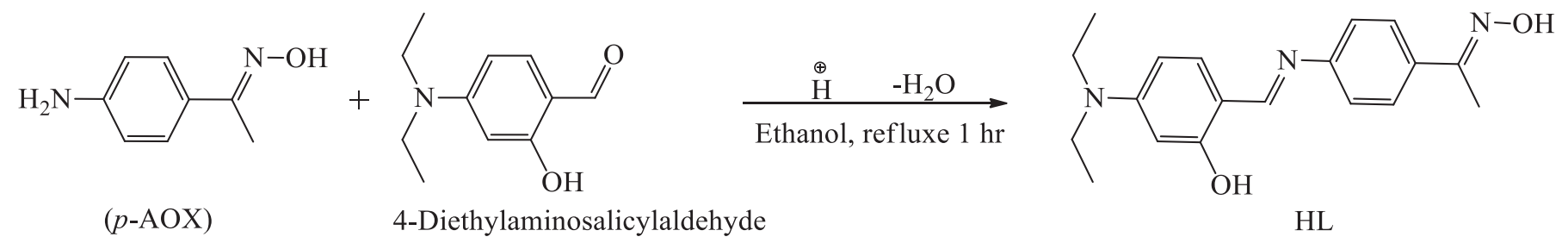

HL

Scheme 2. Synthetic route of ligand HL.

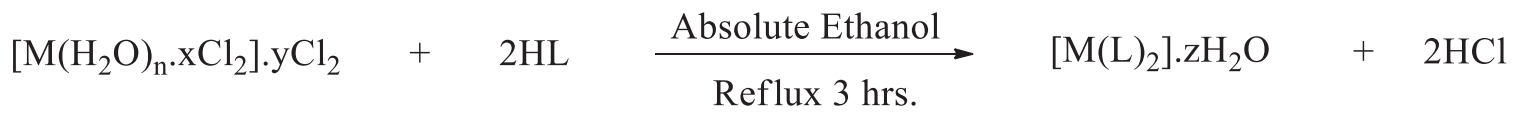

$$
\begin{aligned}
& \mathrm{M}=\mathrm{Co}(\mathrm{II}), \quad \mathrm{M}=\mathrm{Ni}(\mathrm{II}), \\
& \mathrm{n}=6, \mathrm{x}=0, \mathrm{y}=1, \mathrm{z}=0 \quad \mathrm{n}=6, \mathrm{x}=0, \mathrm{y}=1, \mathrm{z}=0.5 \mathrm{H}_{2} \mathrm{O} \quad \mathrm{n}=2, \mathrm{x}=2, \mathrm{y}=0, \mathrm{z}=0
\end{aligned}
$$

Scheme 3. Preparation reaction of chelated complexes.

Analytic Jena spectrophotometer. Magnetic susceptibility of prepared complexes was determined at $(\mathrm{R} . \mathrm{T})^{\circ} \mathrm{C}$ by Auto Magnetic Susceptibility Balance (Sherwood Scientific). Conductivity measurements were recorded at $(\text { R.T })^{\circ} \mathrm{C}$ for solutions of samples in DMSO solvent using an Inolab Multi 740, WTW 82362 Weilhiem-Germany.

\section{Synthesis of [1-(4-aminophenyl)ethanone oxime] (p-AOX)}

The title compound has been prepared according to the literature of Erdal and Mehmet (2005) with some modification. A solution of $p$-Aminoacetophenone ( $p$-ACP) (1.352 g, 10 $\mathrm{mmol}$ ) in $10 \mathrm{ml}$ of absolute ethanol has been added gradually to a mixture solution of hydroxylaminehydrochloride (1.042 g, 15 mmol) and sodium acetate $(1.23 \mathrm{~g}, 15 \mathrm{mmol})$ were dissolved in $\mathrm{EtOH} / \mathrm{H}_{2} \mathrm{O}(35 / 15) \mathrm{ml}$. The reaction mixture was in reflux for 7 hours, and then the volume of reaction mixture reduced by slow evaporation at room temperature. The obtained white needle precipitate was washed with distilled water several times, and then dried at room temperature, and finally recrystallized from hot absolute ethanol. Scheme 1 represents the preparation reaction of ( $p$-AOX).

Synthesis of 1-(4-(4 (diethylamino)-2hydroxybenzylidene) amino) phenyl) ethanone oxime $\mathrm{HL}$

A $15 \mathrm{ml}$ ethanolic solution of $p$-AOX $(1.5 \mathrm{~g}, 10$ mmol) was added gradually to $15 \mathrm{ml}$ ethanolic solution of 4-Diethylaminosalicylaldehyde (1.93 g, $10 \mathrm{mmol})$. The reaction mixture acidified with few drops of glacial acetic acid and refluxed for 1 hour. The golden precipitate, which formed after 0.5 hour, filtered off, washed with diethyl ether, chloroform, and cold absolute ethanol, respectively. Scheme 2 represents the preparation reaction of ligand HL.

\section{Preparation of metal ion complexes}

The following method was used to prepare all metal ion complexes. A solution of $0.5 \mathrm{mmol}$ of each metal chloride salt in $5 \mathrm{ml}$ of absolute ethanol was added slowly to $25-\mathrm{ml}$ hot stirred ethanolic solution of HL $(0.325 \mathrm{~g}, 1 \mathrm{mmol})$. The reaction mixture refluxed for 3 hours. Colored precipitates of metal complexes obtained after cooling the reaction mixture to room temperature. After filtration, all collected precipitates were washed several times with hot chloroform and water, respectively. Scheme 3 represents the preparation reaction of chelated complexes.

\section{RESULTS AND DISCUSSION}

\section{${ }^{1} \mathrm{H}$ and ${ }^{13} \mathrm{C}$ NMR spectra of ligand}

The ${ }^{1} \mathrm{HNMR}$ spectrum of HL, Figure 1, in DMSO- $\mathrm{d}_{6}$ exhibits signals at $\delta=13.59 \mathrm{ppm}, \mathrm{s}, 1 \mathrm{H} ; \delta=11.14 \mathrm{ppm}, \mathrm{s}, 1 \mathrm{H}$; and $\delta=8.71 \mathrm{ppm}, \mathrm{s}, 1 \mathrm{H}$, which were assigned to phenolic (Erdal and Mehmet, 2005) hydroxyl group, oxime hydroxyl group, and azomethine $(\mathrm{CH}=\mathrm{N})$ group protons, respectively (Al-Zaidi and Najat, 2014). The signals of aromatic rings were observed at $\delta=$ $7.67 \mathrm{ppm}, \mathrm{d}, 2 \mathrm{H} ; \delta=7.3 \mathrm{ppm}, \mathrm{d}, 3 \mathrm{H} ; \delta=6.33 \mathrm{ppm}, \mathrm{d}, 1 \mathrm{H}$; and $\delta=6.07, \mathrm{~s}, 1 \mathrm{H}$. The spectrum also revealed three signals at $\delta=$ $3.38 \mathrm{ppm}, \mathrm{q}, 4 \mathrm{H} ; \delta=1.12 \mathrm{ppm}, \mathrm{t}, 6 \mathrm{H}$ (Tzu-Chien et al., 2013); and $\delta=2.16 \mathrm{ppm}, \mathrm{s}, 3 \mathrm{H}$ (Al-Zaidi and Najat, 2014), which were assigned to protons of ethyl and methyl groups, respectively.

The ${ }^{13} \mathrm{CNMR}$ spectrum of HL, Figure 2, in DMSO-d, exhibits chemical shifts at $\delta=163.4 \mathrm{ppm}, 161.2 \mathrm{ppm}$, and $\delta=$ 


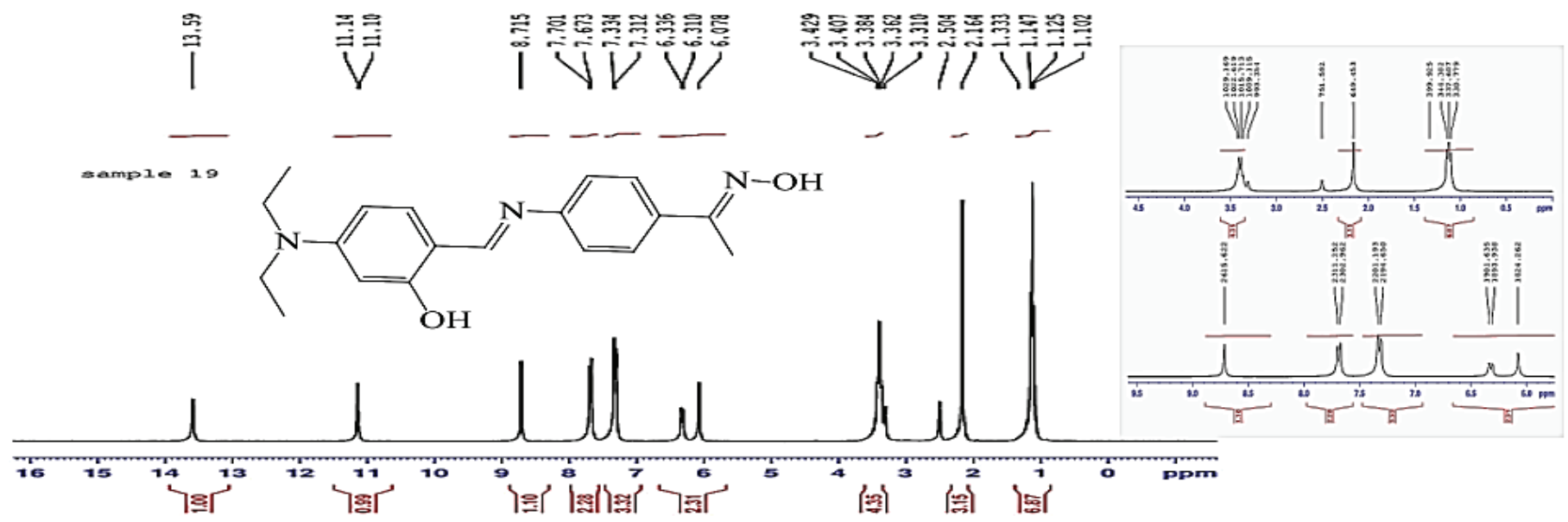

Figure 1. ${ }^{1} \mathrm{HNMR}$ spectrum of HL in DMSO- $d_{6}$.

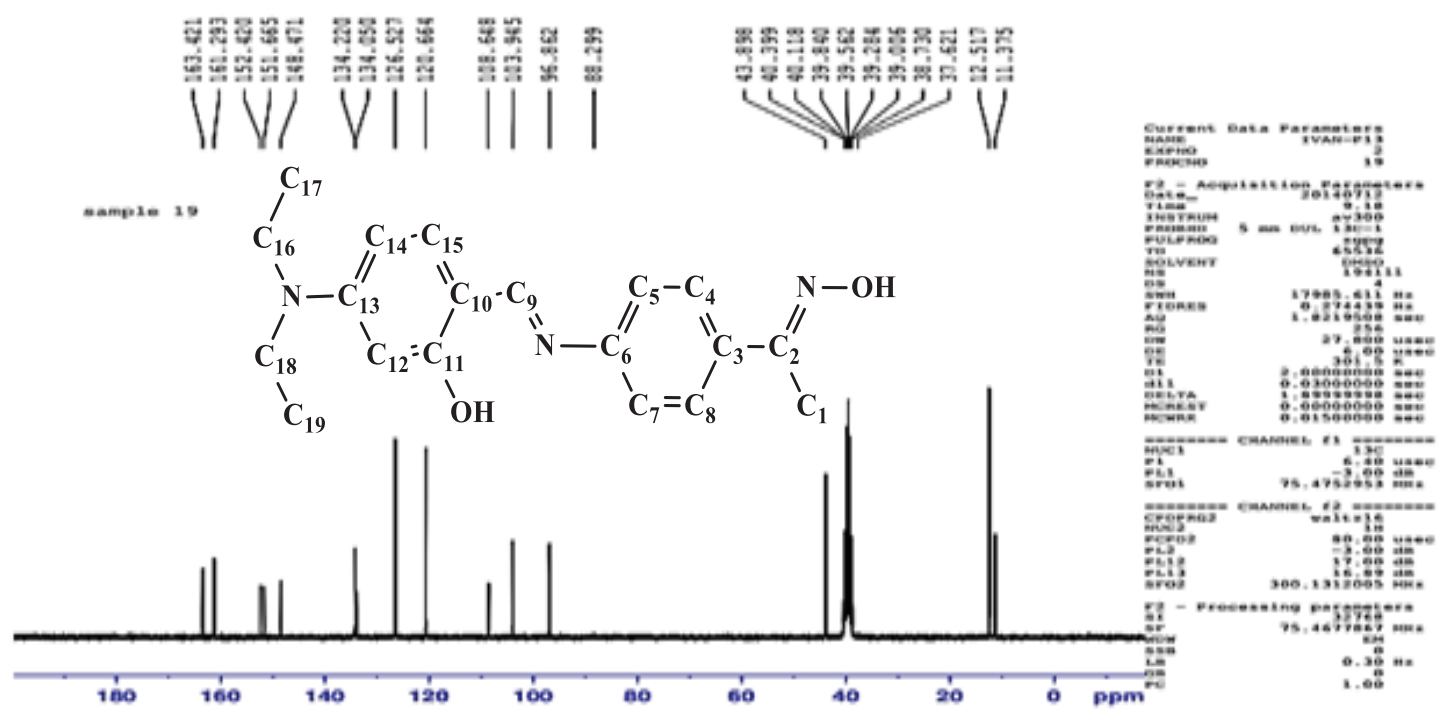

Figure 2. ${ }^{13} \mathrm{CNMR}$ spectrum of HL in DMSO- $d_{6}$.

$152.4 \mathrm{ppm}$, assigned to phenolic $\mathrm{C}-\mathrm{OH}, \mathrm{CH}=\mathrm{N}$, and oxime $\mathrm{C}=\mathrm{NOH}$, respectively (Al-Zaidi and Najat, 2014). The signal of aromatic carbon assigned at $\delta=151.6 \mathrm{ppm}, \mathrm{C}_{6} ; \delta=148.4 \mathrm{ppm}$, $\mathrm{C}_{13} ; \delta=134.2 \mathrm{ppm}, \mathrm{C}_{3} ; \delta=134.0 \mathrm{ppm}, \mathrm{C}_{15} ; \delta=126.5 \mathrm{ppm}, \mathrm{C}_{4}$ and $\mathrm{C}_{8} ; \delta=120.6 \mathrm{ppm}, \mathrm{C}_{5}$ and $\mathrm{C}_{7} ; \delta=108.6 \mathrm{ppm}, \mathrm{C}_{10} ; \delta=103.9 \mathrm{ppm}$, $\mathrm{C}_{14}$; and $\delta=96.8 \mathrm{ppm}, \mathrm{C}_{12}$. The chemical shifts at $\delta=43.9 \mathrm{ppm},=$ $12.5 \mathrm{ppm}$, and $\delta=11.3 \mathrm{ppm}$, assigned to $\left(\mathrm{C}_{16}, \mathrm{C}_{18}\right),\left(\mathrm{C}_{17}, \mathrm{C}_{19}\right)$, and $\left(\mathrm{C}_{1}\right)$ carbons, respectively (Al-Zaidi and Najat, 2014; Erdal and Mehmet, 2005; Tzu-Chien et al., 2013).

\section{Mass spectrum of ligand $\mathrm{HL}$}

The mass spectrum of ligand, Figure 3, showed the mother ion peak at $m / z=325$, as a base peak, which corresponds to $\mathrm{M}^{+}$. Suggested fragmentation pathways and structural assignments of fragments, described in Scheme 4.

\section{X-ray structural determination of HL}

Attempts were made to grow crystals suitable for single crystal X-ray diffraction studies. Suitable crystals were grown by slow evaporation of its chloroform/ethanol solution $(2: 1)$ at room temperature. Single crystal X-ray diffraction results of ligand revealed that the crystals are comprised of monoclinic unit cells in the space group P21/n. Clear light yellow block crystals were obtained. X-ray diffraction showed two molecules in the unit cell. Figure 4 shows only one of the molecules for clarity. All bond lengths are in normal ranges (Peng-Peng et al., 2018). The ligand was found to be neutral. Table 1 represents crystal data and structure refinement parameters for Ligand. A selection of bond lengths and angles are shown in Table 2. 
Target

Rt=6.05 MIN

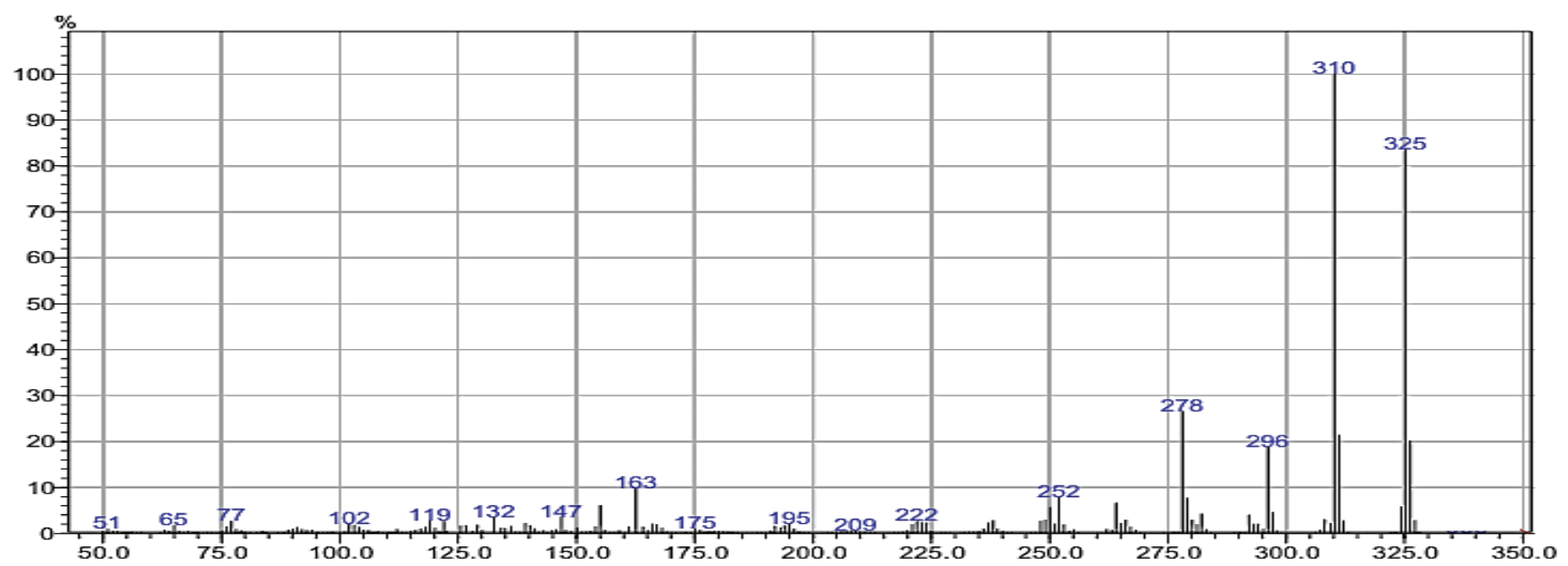

Figure 3. Mass spectrum of HL.

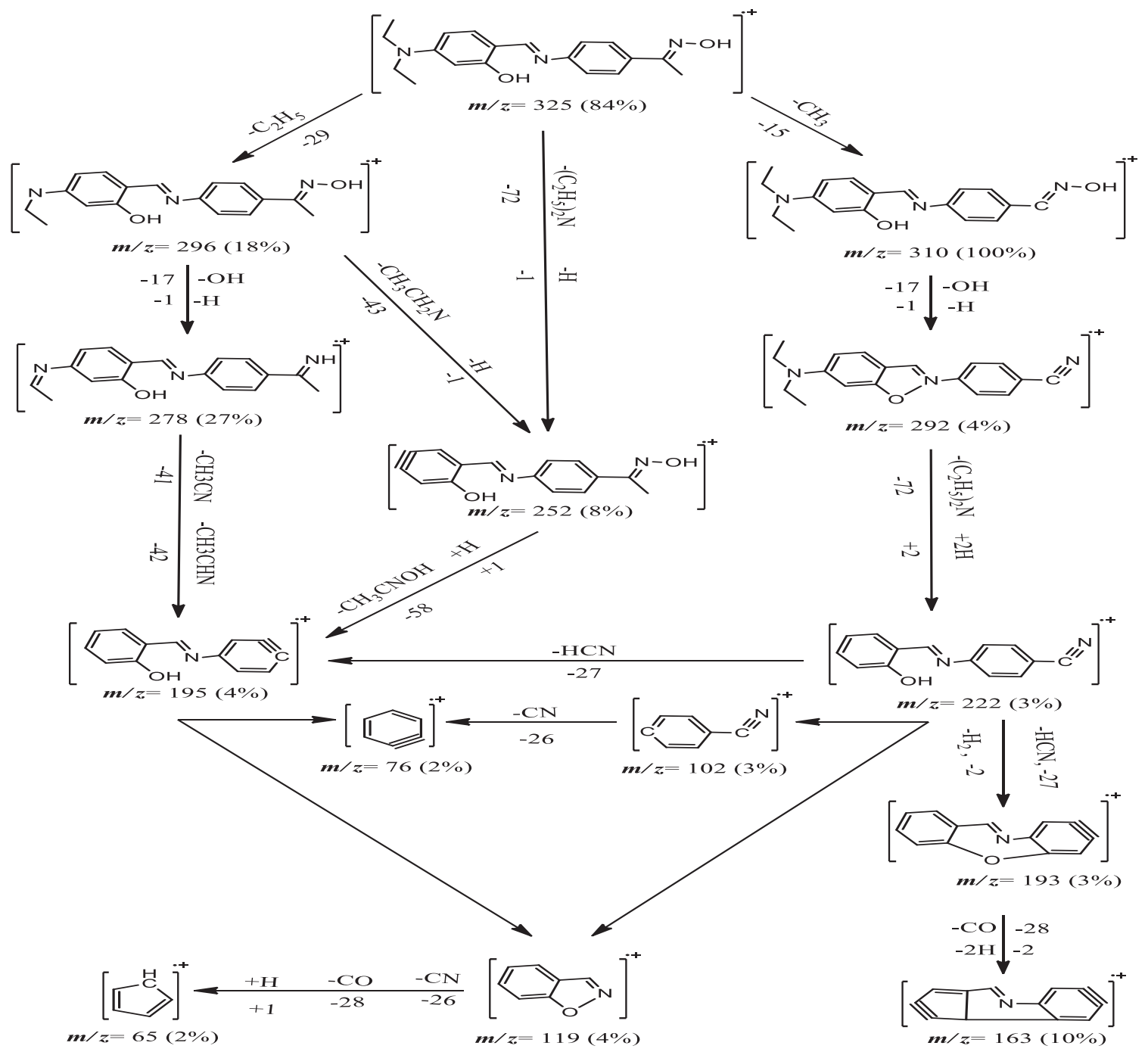

Scheme 4. Suggested fragmentation pathways of HL and structural assignments of fragments. 


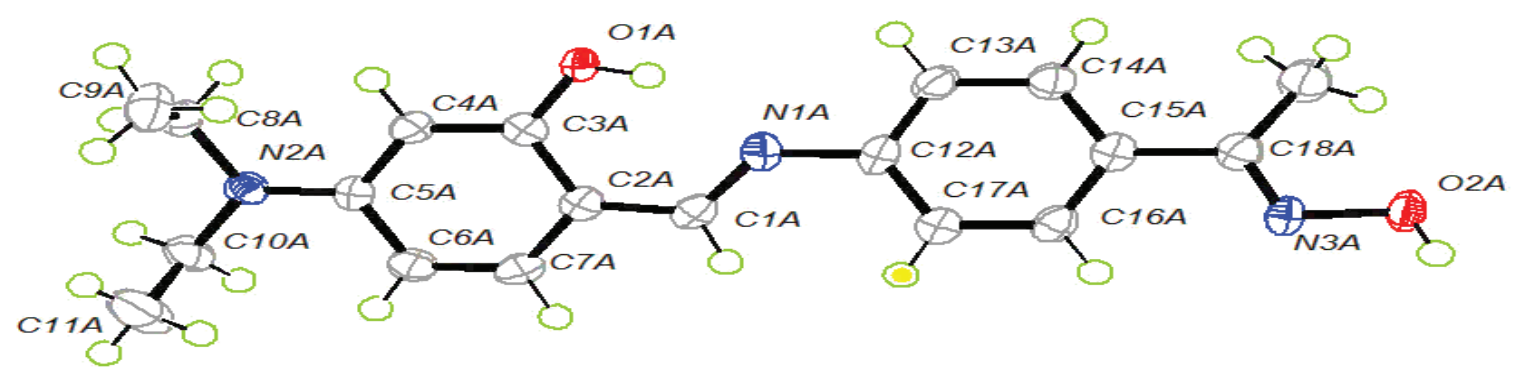

Figure 4. ORTEP ellipsoid plot at $75 \%$ probability of ligand HL.

Table 1. Crystal data and structure refinement for ligand HL.

\begin{tabular}{|c|c|}
\hline Identification code & Ligand HL \\
\hline Empirical formula, (formula weight) & $\mathrm{C}_{19} \mathrm{H}_{23} \mathrm{~N}_{3} \mathrm{O}_{2}, 325.40{\mathrm{~g} . \mathrm{mol}^{-1}}^{-1}$ \\
\hline Temperature/K & 100 \\
\hline Crystal system, (Space group) & Monoclinic, $\left(\mathrm{P} 2_{1} / \mathrm{n}\right)$ \\
\hline $\mathrm{a} / \AA ̊, \mathrm{~b} / \AA ⿻, \mathrm{c} / \AA$ & 17.7086(5), 9.3069(3), 21.9576(6) \\
\hline$\alpha /^{\circ}, \beta /{ }^{\circ}, \gamma /{ }^{\circ}$ & $90,107.596(2), 90$ \\
\hline Volume $/ \AA^{3}$ & $3,449.56(18)$ \\
\hline Z & 8 \\
\hline$\rho_{\text {calg }} \mathrm{g} / \mathrm{cm}^{3}$ & 1.253 \\
\hline$\mu / \mathrm{mm}^{-1}$ & 0.083 \\
\hline $\mathrm{F}(000)$ & 1392.0 \\
\hline Crystal size $/ \mathrm{mm}^{3}$ & $0.34 \times 0.11 \times 0.06$ \\
\hline Radiation & $\operatorname{MoK} \alpha(\lambda=0.71073)$ \\
\hline $2 \Theta$ range for data collection $/{ }^{\circ}$ & 3.528 to 55.08 \\
\hline Index ranges & $\begin{array}{c}-23 \leq \mathrm{h} \leq 22,-12 \leq \mathrm{k} \leq 12,-28 \leq 1 \\
\leq 28\end{array}$ \\
\hline Reflections collected & 59,282 \\
\hline Independent reflections & $7915\left(R_{\mathrm{int}}=0.1049, R_{\mathrm{sigma}}=0.0649\right)$ \\
\hline Data/restraints/parameters & $7,915 / 0 / 443$ \\
\hline Goodness-of-fit on $F^{2}$ & 1.011 \\
\hline Final $R$ indexes $[\mathrm{I} \geq 2 \sigma(\mathrm{I})]$ & $R_{1}=0.0523, \mathrm{w} R_{2}=0.1137$ \\
\hline Final R indexes (all data) & $\mathrm{R}_{1}=0.1066, \mathrm{w} R_{2}=0.1410$ \\
\hline Largest diff. peak/hole / e $\AA^{-3}$ & $0.67 /-0.63$ \\
\hline
\end{tabular}

\section{Characterization of metal ion complexes}

The physical properties, yield percentages, and metal content of ligand HL and its metal ion complexes are shown in Table 3.

\section{FT-IR Spectra of Ligand HL and its metal ion complexes}

FTIR spectrum of ligand did not show the stretching frequency of phenolic (O-H) (Franz et al., 2016) because of its involvement in hydrogen bonding (Intra-ligand hydrogen bond) with lone electron pair of azomethine nitrogen atom $(\mathrm{O}-\mathrm{H} \ldots \ldots \mathrm{N})$, while the stretching frequency of oxime $(\mathrm{O}-\mathrm{H})(\mathrm{Al}-$ Zaidi et al., 2018) revealed at $3,132 \mathrm{~cm}^{-1}$. The stretching frequency of azomethine
Table 2. Selected bond lengths and angles for ligand.

\begin{tabular}{lccc}
\hline \multicolumn{2}{c}{ Bond angles $\left({ }^{\circ}\right)$} & \multicolumn{2}{c}{ Bond lengths $(\AA)$} \\
\hline C1A-N1A-C12A & $126.59(18)$ & C1A-N1A & $1.338(3)$ \\
N1A-C1A-C2A & $123.52(19)$ & C12A-N1A & $1.417(3)$ \\
C13A-C12A-N1A & $117.21(18)$ & C1A-C2A & $1.391(3)$ \\
C17A-C12A-N1A & $123.10(19)$ & N2A-C5A & $1.360(3)$ \\
N2A-C5A-C4A & $121.12(19)$ & N2A-C10A & $1.466(3)$ \\
N2A-C5A-C6A & $120.60(18)$ & C3A-O1A & $1.313(2)$ \\
N2A-C8A-C9A & $112.99(18)$ & N3A-O2A & $1.409(2)$ \\
\hline
\end{tabular}

linkage in metal complexes shifted to lower frequencies (4-10 $\mathrm{cm}^{-1}$ ) compared with that of free ligand (Al-Zaidi et al., 2018). This confirms the participation of this group in coordination with metal ions. The stretching frequency of phenolic $(\mathrm{C}-\mathrm{O})$ bond has been shifted by $14-20 \mathrm{~cm}^{-1}$ to lower wave numbers (Hao-Ran et $a l ., 2017)$ in spectra of prepared complexes. This also indicated the participation of phenolic oxygen atom in coordination with metal ions after losing its proton. New vibration bands have been noticed in spectra of prepared complexes at wave number ranges $571-563 \mathrm{~cm}^{-1}$ and $440-432 \mathrm{~cm}^{-1}$ assigned to $v(\mathrm{M}-\mathrm{O})$ and $v(\mathrm{M}-\mathrm{N})$ vibrations, respectively (Franz et al., 2016; Kumar et al., 2018). The main stretching frequencies of characteristic bands related to the free ligand and its metal complexes and their assignments are presented in Table 4. Figures 5-8 represent the FTIR spectra of ligand HL and its related complexes.

\section{Electronic spectra and magnetic properties of prepared complexes}

The magnetic susceptibility measurements and electronic spectral data have been used to establish the structure of complexes. The effective magnetic moment ( $\mu$ eff) values have been observed at room temperature $(300 \mathrm{~K})$ for the complexes listed in Table 5 with electronic spectra of ligand and its metal ion complexes. The electronic spectra of ligand and its metal ion complexes recorded in DMSO solutions at wavelengths range 200-800 nm.

Table 3. Physical properties, yield, and Metal percentages of prepared compounds.

\begin{tabular}{llccccc}
\hline Comp. & Chemical formula & M.Wt g.mol ${ }^{-1}$ & Color & M.P $\left({ }^{\circ} \mathbf{C}\right)$ & Yield\% & M\% Calc. $($ found) \\
\hline $\mathrm{HL}$ & {$\left[\mathrm{C}_{19} \mathrm{H}_{23} \mathrm{~N}_{3} \mathrm{O}_{2}\right]$} & 325.40 & Golden & $210-213$ & 71 \\
{$\left[\mathrm{Co}(\mathrm{L})_{2}\right]$} & {$\left[\mathrm{C}_{38} \mathrm{H}_{44} \mathrm{CoN}_{6} \mathrm{O}_{4}\right]$} & 707.73 & Purple & $225-228$ & 57 \\
{$\left[\mathrm{Ni}(\mathrm{L})_{2}\right] \cdot 0.5 \mathrm{H}_{2} \mathrm{O}$} & {$\left[\mathrm{C}_{38} \mathrm{H}_{44} \mathrm{~N}_{6} \mathrm{NiO}_{4}\right] \cdot 0.5 \mathrm{H}_{2} \mathrm{O}$} & 716.50 & Orange & $294-296$ & $8.33(7.56)$ \\
{$\left[\mathrm{Cu}(\mathrm{L})_{2}\right]$} & $\mathrm{C}_{38} \mathrm{H}_{44} \mathrm{CuN}_{6} \mathrm{O}_{4}$ & 712.34 & Brown & $272-274$ & $8.19(7.29)$ & 60 \\
\hline
\end{tabular}


Table 4. FTIR spectral data $\left(\mathrm{cm}^{-1}\right)$ of ligand HL and its complexes.

\begin{tabular}{|c|c|c|c|c|c|}
\hline Comp. & $v(\mathrm{O}-\mathrm{H})$ Phenol (oxime) & $\begin{array}{c}v(\mathrm{C}-\mathrm{H}) \\
\text { Arom. (Alph.) }\end{array}$ & $\begin{array}{l}v(C=N) \\
v(C=C)\end{array}$ & $\begin{array}{c}v(\mathrm{C}-\mathrm{O}) \\
v(\mathrm{C}-\mathrm{N}) \\
v(\mathrm{~N}-\mathrm{O})\end{array}$ & $\begin{array}{l}v(\mathbf{M}-\mathbf{O}) \\
\mathbf{v}(\mathbf{M}-\mathbf{N})\end{array}$ \\
\hline \multirow{3}{*}{$\mathrm{HL}$} & \multirow{3}{*}{$\begin{array}{c}--- \\
(3132) \mathrm{w}\end{array}$} & \multirow{2}{*}{$3050(w)$} & \multirow{2}{*}{ 1616(s) } & \multirow{2}{*}{$\begin{array}{l}1277(\mathrm{~m}) \\
1196(\mathrm{~m})\end{array}$} & \\
\hline & & & & & ---- \\
\hline & & $(2974-2843)(w)$ & $1587,1518(\mathrm{~s})$ & & --- \\
\hline \multirow{3}{*}{ Co } & \multirow{3}{*}{$\begin{array}{c}--- \\
(3167) \mathrm{w}\end{array}$} & \multirow{3}{*}{$\begin{array}{l}3072,3040(w) \\
(2972-2870)(w)\end{array}$} & \multirow{2}{*}{ 1612(s) } & $1257(\mathrm{~m})$ & \multirow{2}{*}{$563(w)$} \\
\hline & & & & \multirow{2}{*}{$1188(\mathrm{~m})$} & \\
\hline & & & $1564,1496(\mathrm{~s})$ & & $432(w)$ \\
\hline \multirow{4}{*}{$\mathrm{Ni}$} & \multirow{4}{*}{$(3201) \mathrm{w}$} & \multirow{4}{*}{$\begin{array}{l}3070,3039(w) \\
(2974-2870)(w)\end{array}$} & \multirow[b]{2}{*}{ 1606(s) } & $1263(\mathrm{~m})$ & \multirow{4}{*}{$\begin{array}{l}571(w) \\
438(w)\end{array}$} \\
\hline & & & & & \\
\hline & & & $1577,1500(\mathrm{~s})$ & $1194(\mathrm{~m})$ & \\
\hline & & & & 1003(w) & \\
\hline \multirow{3}{*}{$\mathrm{Cu}$} & & & & $1259(\mathrm{~m})$ & \\
\hline & --- & $3068,3032(w)$ & $1608(\mathrm{~s})$ & \multirow{2}{*}{ 1194(m) } & $567(w)$ \\
\hline & $(3167) w$ & $(2972-2871)(w)$ & $1574,1498(\mathrm{~s})$ & & $440(w)$ \\
\hline
\end{tabular}

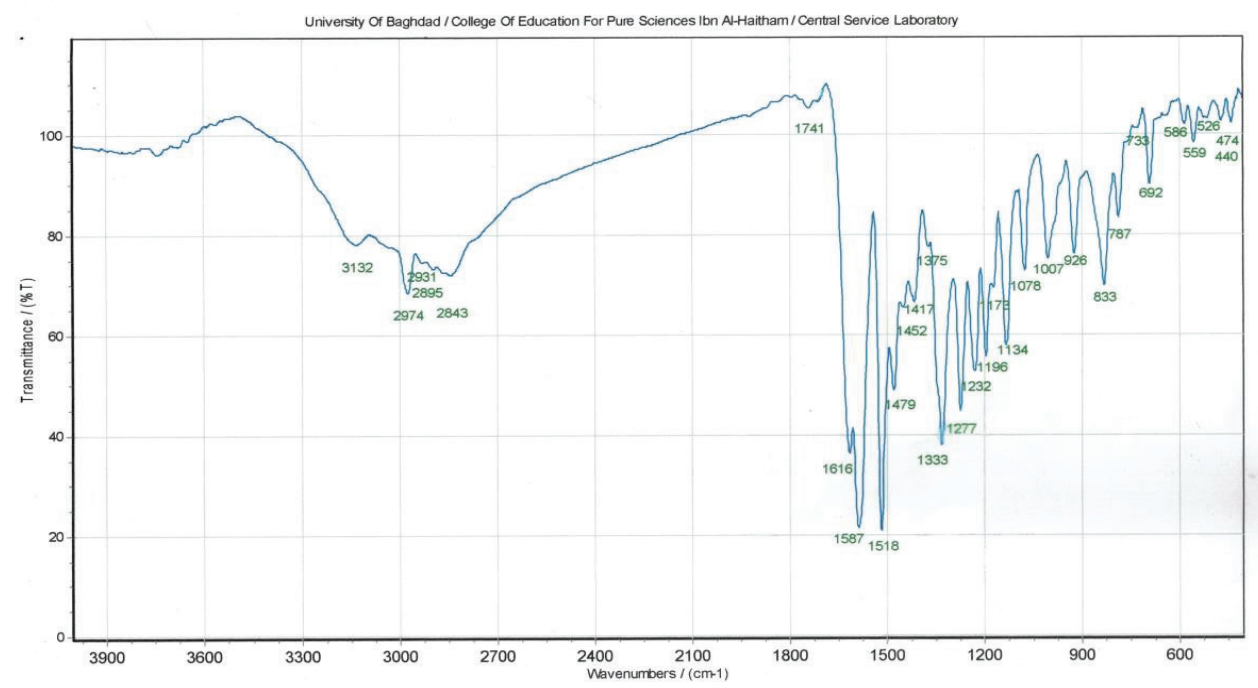

Figure 5. FTIR spectra of HL.

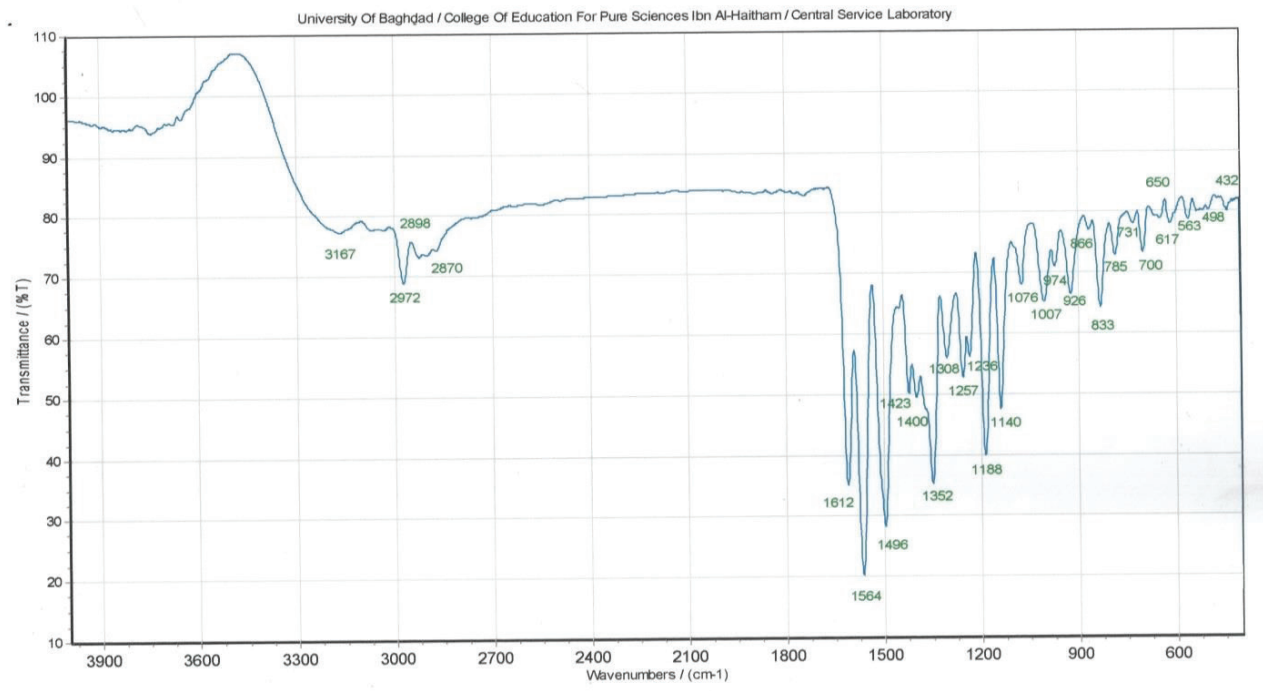

Figure 6. FTIR spectra of $\left[\mathrm{Co}(\mathrm{L})_{2}\right]$ complex. 


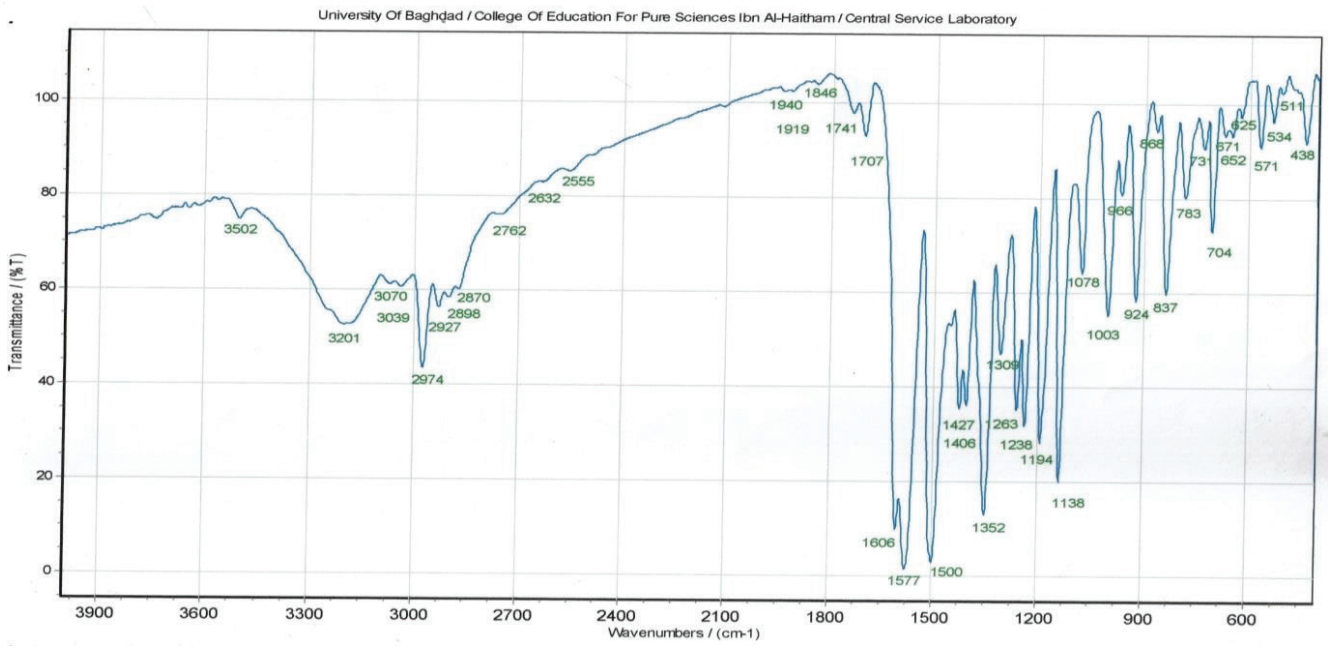

Figure 7. FTIR spectra of $\left[\mathrm{Ni}(\mathrm{L})_{2}\right] \cdot 0 \cdot 5 \mathrm{H}_{2} \mathrm{O}$ complex.

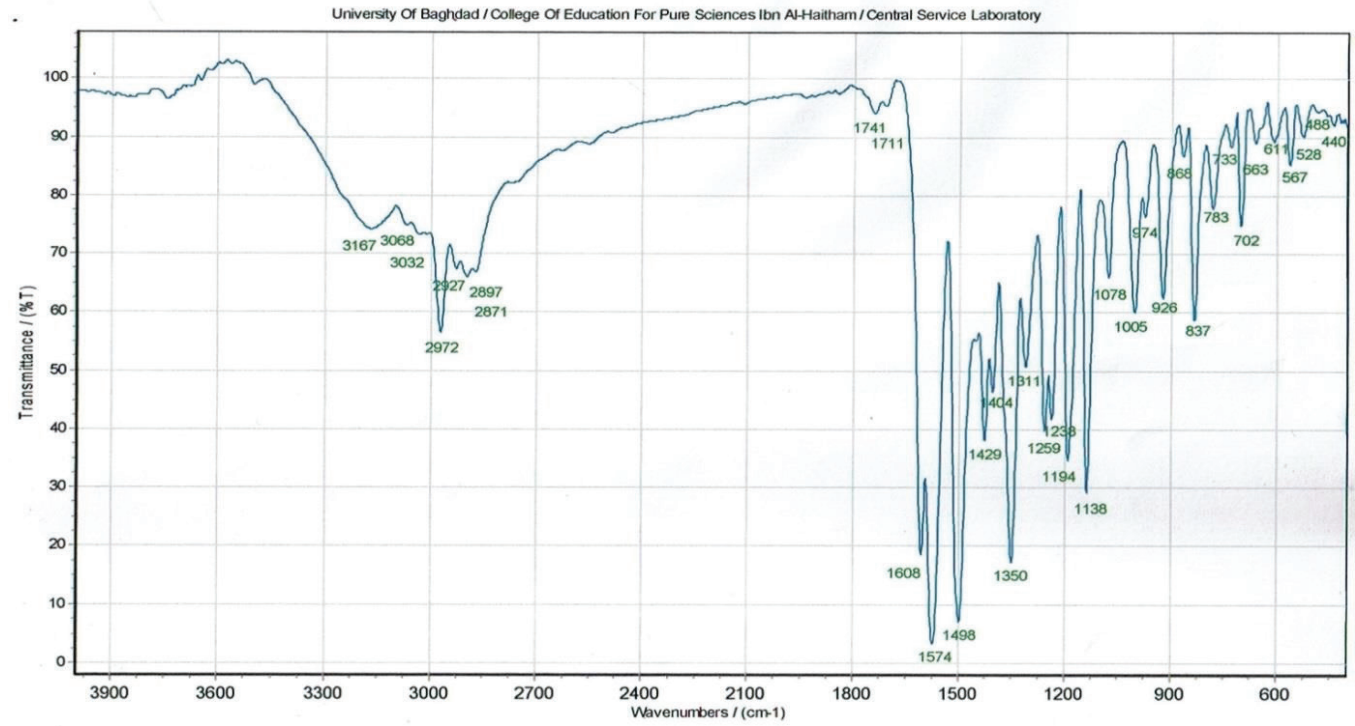

Figure 8. FTIR spectra of $\left[\mathrm{Cu}(\mathrm{L})_{2}\right]$ complex.

Table 5. Electronic spectral data of HL and prepared complexes.

\begin{tabular}{|c|c|c|c|c|c|}
\hline Compound & $\lambda_{\max } \mathrm{nm},\left(v^{-} \mathbf{c m}^{-1}\right)$ & Assignment & $\mu_{\mathrm{eff}}$ (B.M) & Molar conductance $\mu \mathrm{s} . \mathrm{cm}^{-1}$ & Geometry \\
\hline $\mathrm{HL}$ & $396(25,252)$ & Ligand field & --- & & --- \\
\hline \multirow{3}{*}[\mathrm{Co}(\mathrm{L})_{2}]{} & $402(24,875)$ & MLCT & \multirow{2}{*}{3.87} & \multirow{3}{*}{ (0.6) } & \multirow{3}{*}{ T.h } \\
\hline & $837(11,947)$ & ${ }^{4} \mathrm{~A}_{2}(\mathrm{~F}) \rightarrow{ }^{4} \mathrm{~T}_{1}(\mathrm{P})\left(\mathrm{v}_{3}\right)$ & & & \\
\hline & $390(25,641)$ & MLCT & \multirow[b]{2}{*}{0.00} & & \\
\hline \multirow[t]{2}{*}[\mathrm{Ni}(\mathrm{L})_{2}]{$\cdot 0 \cdot 5 \mathrm{H}_{2} \mathrm{O}$} & $\begin{array}{l}430(23,255) \\
566(17,667)\end{array}$ & $\begin{array}{l}{ }^{1} A_{1 g} \rightarrow{ }^{1} B_{1 g}\left(v_{2}\right) \\
{ }^{1} A_{1 g} \rightarrow{ }^{1} A_{2 g}\left(v_{1}\right)\end{array}$ & & (1.2) & S.P \\
\hline & $391(25,575)$ & MLCT & \multirow[b]{2}{*}{1.79} & \multirow[b]{2}{*}{ (1.3) } & \multirow[b]{2}{*}{ S.P } \\
\hline$\left[\mathrm{Cu}(\mathrm{L})_{2}\right]$ & $\begin{array}{l}520(19,230) \\
567(17,636)\end{array}$ & ${ }^{2} \mathrm{~B}_{1} \mathrm{~g} \rightarrow{ }^{2} \mathrm{~A}_{1} \mathrm{~g}\left(\mathrm{v}_{1}\right)^{2} \mathrm{~B}_{1} \mathrm{~g} \rightarrow{ }^{2} \mathrm{~B}_{2} \mathrm{~g}\left(\mathrm{v}_{2}\right)$ & & & \\
\hline
\end{tabular}

The UV-Vis spectrum of the yellow solution of prepared ligand reveals only one high-intensity peak at $396 \mathrm{~nm}$, $25,252 \mathrm{~cm}^{-1}$, assigned to intra-ligand charge transfer spectra
(Al-Zaidi et al., 2018). This peak shifted in spectra of complexes to lower and higher wavelengths, upon coordination of the ligand (Hao-Ran et al., 2017; Dong et al., 2011). The spectra 

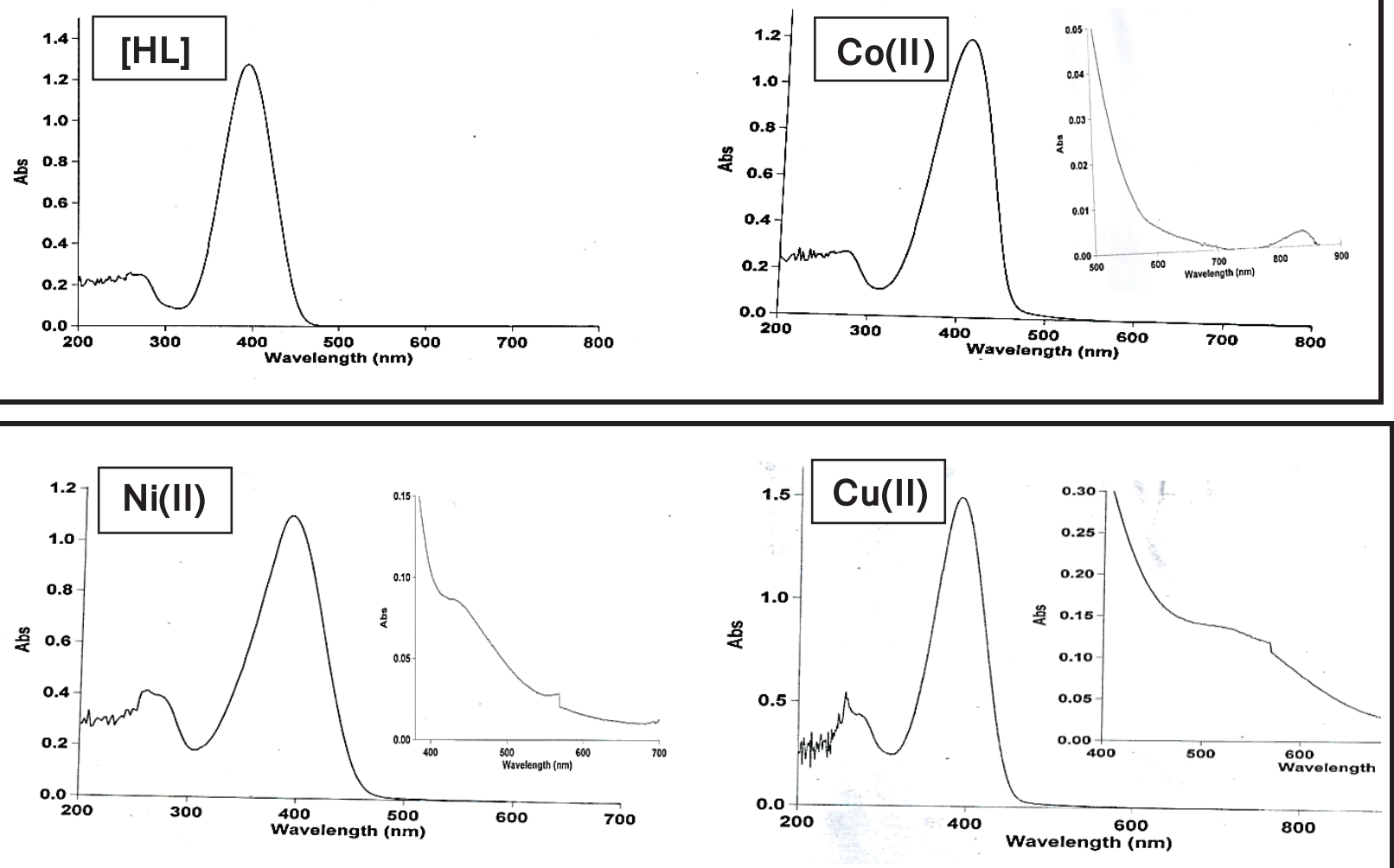

Figure 9. Electronic spectra of HL and its complexes.

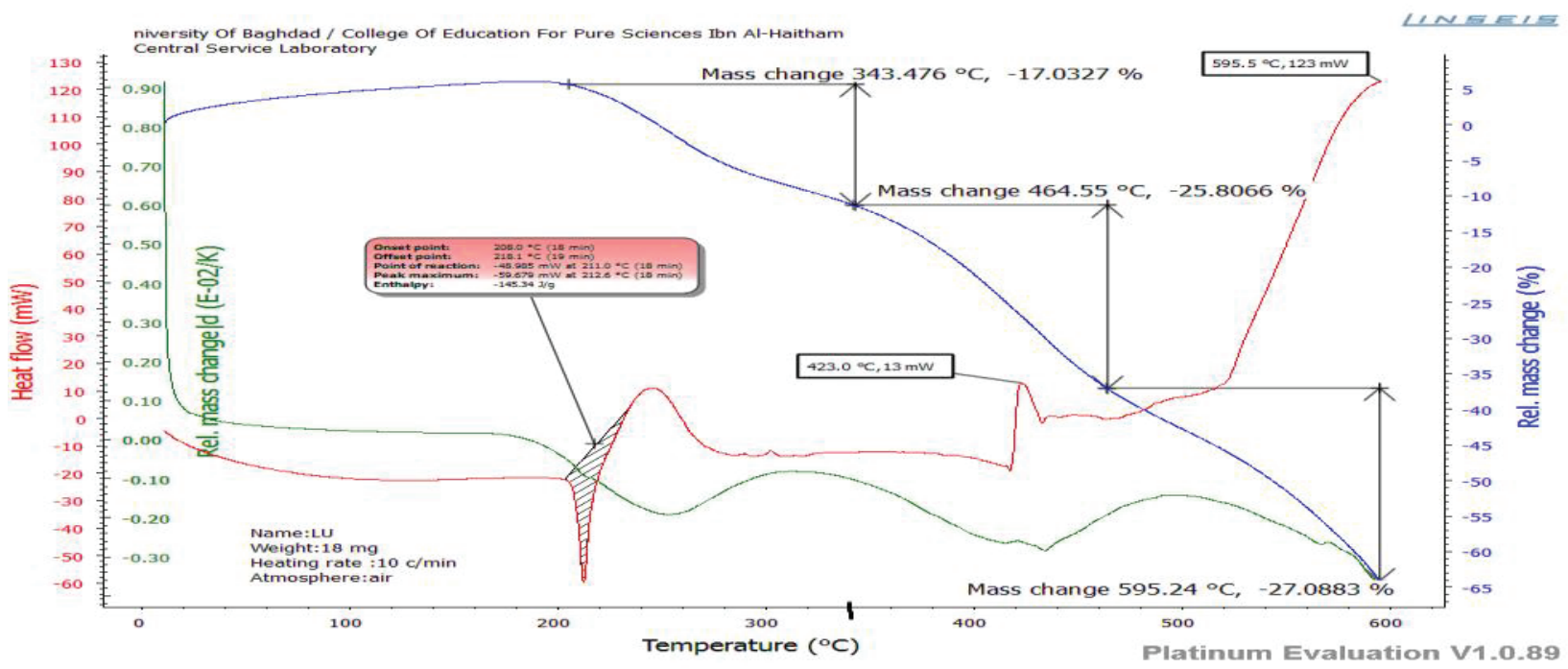

Figure 10. TG/DTG/DTA curves of HL.

of $\mathrm{Co}(\mathrm{II}), \mathrm{Ni}(\mathrm{II})$, and $\mathrm{Cu}(\mathrm{II})$ complexes showed high-intensity peaks at $402 \mathrm{~nm}, 24875 \mathrm{~cm}^{-1} ; 390 \mathrm{~nm}, 25,641 \mathrm{~cm}^{-1}$; and $391 \mathrm{~nm}$, $25,575 \mathrm{~cm}^{-1}$ related to MLCT transition (Hao-Ran et al., 2017). At high concentration, the spectrum of $\mathrm{Co}$ (II) complex revealed low-intensity absorption peaks at $837 \mathrm{~nm}, 11947 \mathrm{~cm}^{-1}$, assigned to higher energy third spin allowed ${ }^{4} \mathrm{~A}_{2}(\mathrm{~F}) \rightarrow{ }^{4} \mathrm{~T}_{1}(\mathrm{P})\left(\mathrm{v}_{3}\right)$ transition of the tetrahedral environment (Mehdi et al., 2002). High concentration of orange solution of $\mathrm{Ni}$ (II) complex exhibited absorption peaks at $430 \mathrm{~nm}, 23,255 \mathrm{~cm}^{-1}$ and $566 \mathrm{~nm}, 17,667$ $\mathrm{cm}^{-1}$, both peaks were assigned to ${ }^{1} \mathrm{~A}_{1 \mathrm{~g}} \rightarrow{ }^{1} \mathrm{~B}_{1 \mathrm{~g}}\left(\mathrm{v}_{2}\right)$ and ${ }^{1} \mathrm{~A}_{1 \mathrm{~g}} \rightarrow$ ${ }^{1} \mathrm{~A}_{2 \mathrm{~g}}\left(v_{1}\right)$, respectively, of square planar environment (Anitha et al., 2013). The third expected transition of Ni(II) square planar complexes ${ }^{1} \mathrm{~A}_{1 \mathrm{~g}} \rightarrow{ }^{1} \mathrm{E}_{\mathrm{g}}\left(\mathrm{v}_{3}\right)$ may be obscured by high-intensity charge transfer transition peak. At high concentration, the 


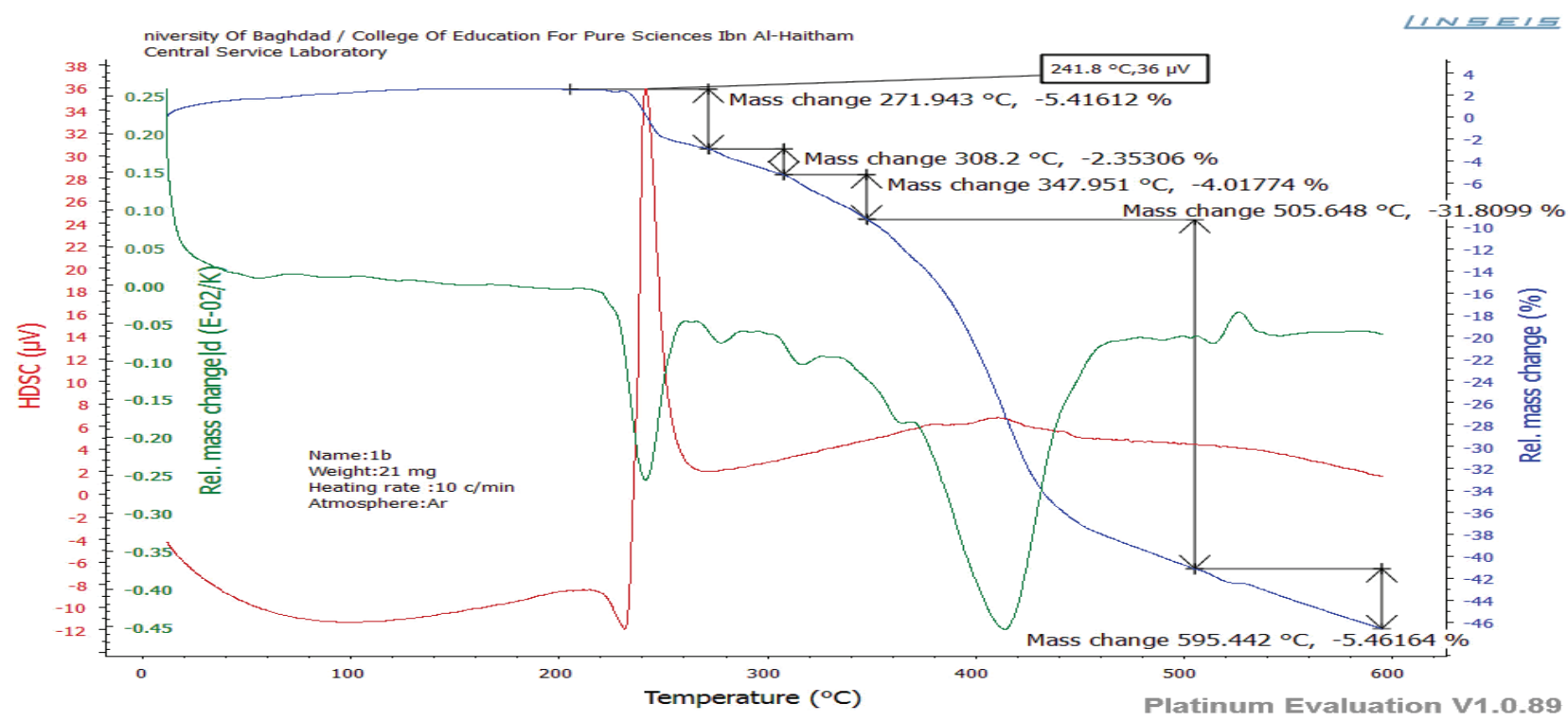

Figure 11. TG/DTG/DTA curves of $\left[\mathrm{Co}(\mathrm{L})_{2}\right]$ complex.

spectrum of $\mathrm{Cu}(\mathrm{II})$ complex showed two new peaks in visible region at $567 \mathrm{~nm}, 17,636 \mathrm{~cm}^{-1}$ and $520 \mathrm{~nm}, 19,230 \mathrm{~cm}^{-1}$ related to ${ }^{2} \mathrm{~B}_{1} \mathrm{~g} \rightarrow{ }^{2} \mathrm{~A}_{1} \mathrm{~g}\left({ }_{1}\right)$ and ${ }^{2} \mathrm{~B}_{1} \mathrm{~g} \rightarrow{ }^{2} \mathrm{~B}_{2} \mathrm{~g}\left(v_{2}\right)$ transitions of square planar environment (Takjoo and Centore, 2013; Thavuduraj et al., 2012). Figure 9 represents the electronic spectra of HL and its metal complexes.

\section{Thermal analysis}

TG/DTG/DTA curves for HL and its complexes were obtained at a heating rate of $10^{\circ} \mathrm{C} /$ minute under air atmosphere for $\mathrm{HL}$ and Argon atmosphere for $\mathrm{Co}$ (II) and $\mathrm{Ni}$ (II) complexes within a temperature range of $25^{\circ} \mathrm{C}-625^{\circ} \mathrm{C}$. Thermal analysis guides us to detect and compare between lattice and crystal water molecules in the coordination compounds, as well as their thermal stability and degradation mode under controlled heating rate (Ratiram et al., 2015). The lost mass in each decomposition step was compared with that theoretically expected to lose from the compound structure. Both of DTG and DTA studies represent potential supporting to the structural transformation that observed by TG curves. Analysis studies of TG/DTG/DTA curves, related to $\left[\mathrm{Co}(\mathrm{L})_{2}\right]$ and $\left[\mathrm{Ni}(\mathrm{L})_{2}\right] \cdot 0.5 \mathrm{H}_{2} \mathrm{O}$ complex, revealed different decomposition pattern from that of free HL. This difference caused by the HL molecules became more restricted than free HL after coordination with $\mathrm{Co}(\mathrm{II})$ and $\mathrm{Ni}$ (II) via their functional groups, in addition to the potential probability of the existence of lattice and coordinated water molecules or one of them.

The analysis of TG/DTG/DTA curves of ligand HL, Figure 10, showed that thermal decomposition occurs through three steps. The first degradation step began at $208^{\circ} \mathrm{C}-343^{\circ} \mathrm{C}$ with $\mathrm{T}_{\text {DTG }}$ at $256^{\circ} \mathrm{C}$, assigned to Obs. $17.03 \%$, Calc. $17.84 \%$ mass loss may be attributed to the removal of $\left(\mathrm{CH}_{3}-\mathrm{C}=\mathrm{N}-\mathrm{OH}\right)$ part from ligand backbone. This step combined with two different processes; the first is the endothermic process $\left(\mathrm{T}_{\mathrm{DTA}}\right)$ peak at $213^{\circ} \mathrm{C}$, which assigned to melting point [melting point determined by capillary tube system in static air was $\left.\left(210^{\circ} \mathrm{C}-213^{\circ} \mathrm{C}\right)\right]$ and the second is exothermic process $\left(\mathrm{T}_{\mathrm{DTA}}\right)$ peak at $245^{\circ} \mathrm{C}$, for removing part of organic moiety. The second degradation step initially at $343^{\circ} \mathrm{C}-464^{\circ} \mathrm{C}$ of broad $\left(\mathrm{T}_{\mathrm{DTG}}\right)$ peak at $436^{\circ} \mathrm{C}$ and sharp exothermic $\left(\mathrm{T}_{\mathrm{DTA}}\right)$ peak at $423^{\circ} \mathrm{C}$ related to decomposition of $\left[\mathrm{N}\left(\mathrm{C}_{2} \mathrm{H}_{5}\right)_{2}\right]$ from ligand backbone (Obs. $25.80 \%$, Calc. $22.15 \%$ ). Third decomposition step was observed at a temperature range $\left(464^{\circ} \mathrm{C}-595^{\circ} \mathrm{C}\right)$, assigned to Obs. $27.08 \%$, Calc. $27.69 \%$ mass loss may be due to consumption of $\left[\mathrm{C}_{6} \mathrm{H}_{4} \mathrm{~N}\right]$ part from ligand backbone, with no detection of peaks related to both $\mathrm{T}_{\mathrm{DTG}}$ and $\mathrm{T}_{\mathrm{DTA}}$. In general, the ligand $\mathrm{HL}$ is stable up to $208^{\circ} \mathrm{C}$ and $69.91 \%$ of it completed decomposed at $595^{\circ} \mathrm{C}$.

The analysis studies of TG/DTG/DTA curves related to $\left[\mathrm{Co}(\mathrm{L})_{2}\right]$ complex, Figure 11 , exhibited that thermal decomposition occurs through five steps. The lack of mass loss up to $205^{\circ} \mathrm{C}$ confirms the absence of water molecules in complex environments (Erdal et al., 2016, Marisa et al., 1999). The first pyrolysis step started at $228^{\circ} \mathrm{C}-271^{\circ} \mathrm{C}$ with $\mathrm{T}_{\text {DTG }}$ at $241{ }^{\circ} \mathrm{C}$, due to Obs. $5.41 \%$, Calc. $4.80 \%$ mass loss may be assigned to the removal of $2 \mathrm{OH}$ groups from ligand backbone. This step combined with two different processes; the first is the endothermic process $\mathrm{T}_{\text {DTA }}$ peak at $226^{\circ} \mathrm{C}$, which assigned to melting point (melting point determined by capillary tube system in static air was $225^{\circ} \mathrm{C}-228^{\circ} \mathrm{C}$ ) and the second is exothermic process with sharp $\mathrm{T}_{\mathrm{DTA}}$ peak at $241^{\circ} \mathrm{C}$ for removing two hydroxyl groups. The second and third decomposition steps included the removal of one methyl and one ethyl groups at $271^{\circ} \mathrm{C}-308^{\circ} \mathrm{C}$ (Obs. 2.12\%, Calc. 2.35\%), mass loss, with weak ( $\mathrm{T}_{\mathrm{DTG}}$ ) peak at $276^{\circ} \mathrm{C}$ and $308^{\circ} \mathrm{C}-347^{\circ} \mathrm{C}$ (Obs. $4.01 \%$, Calc. $4.10 \%$ ), mass loss, with weak $\left(\mathrm{T}_{\mathrm{DTG}}\right)$ peak at $316^{\circ} \mathrm{C}$, respectively. These two steps exhibited as endothermic processes with one weak and broad $\left(\mathrm{T}_{\text {DTA }}\right)$ peak at $264^{\circ} \mathrm{C}$. The fourth and fifth decomposition steps involved the removal of $\left[\mathrm{C}_{6} \mathrm{H}_{4}-\mathrm{CN}, \mathrm{CH}_{3} \mathrm{CH}_{2} \mathrm{~N}, \mathrm{~N}-\left(\mathrm{C}_{2} \mathrm{H}_{5}\right)_{2}\right]$, and $\left[\mathrm{CH}_{3} \mathrm{CN}\right]$ at $347^{\circ} \mathrm{C}-505^{\circ} \mathrm{C}$, Obs. $31.80 \%$, Calc. $30.69 \%$, mass loss, with weak $\mathrm{T}_{\text {DTG }}$ peak at $408^{\circ} \mathrm{C}$ and $505^{\circ} \mathrm{C}-595^{\circ} \mathrm{C}$, (Obs. $5.46 \%$, Calc. $5.79 \%$ ), mass loss, with weak $\mathrm{T}_{\text {DTG }}$ peak at $516^{\circ} \mathrm{C}$, 


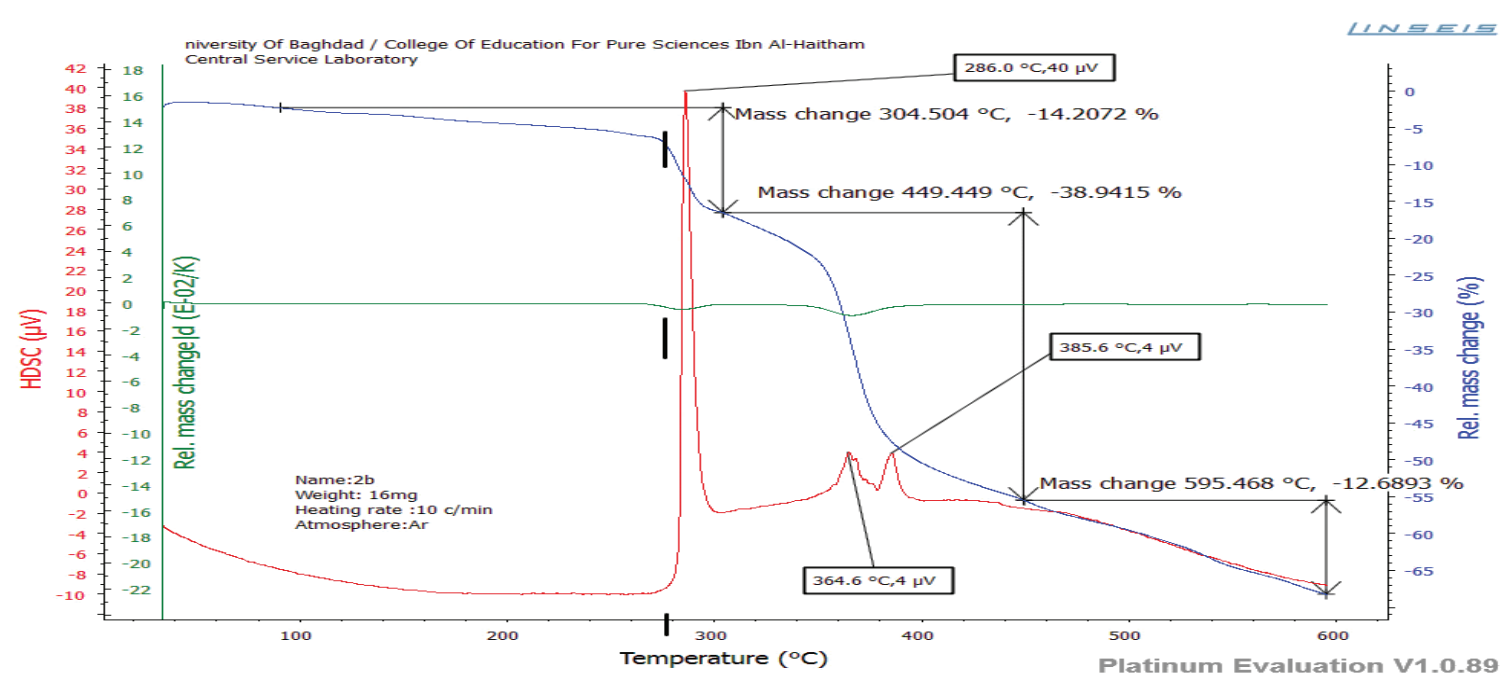

Figure 12. TG/DTG/DTA curves of $\left[\mathrm{Ni}(\mathrm{L})_{2}\right] \cdot 0.5 \mathrm{H}_{2} \mathrm{O}$ complex.

Table 6. TG/DTG/DTA data of HL and its complexes with decomposition steps

\begin{tabular}{|c|c|c|c|c|c|c|c|}
\hline Comp. & Step & Temperature range $\left({ }^{\circ} \mathrm{C}\right)$ & $\begin{array}{c}\text { DTG }_{\max } \\
T_{\text {DTG }}\end{array}$ & & & $\begin{array}{l}\text { Mass loss } \\
\text { Obs/Calc }\end{array}$ & Assignment \\
\hline \multirow{3}{*}{$\mathrm{HL}$} & $1 \mathrm{st}$ & $208-343$ & 256 & 213 & 245 & $17.03 / 17.84$ & $-\left[\mathrm{CH}_{3}-\mathrm{C}=\mathrm{N}-\mathrm{OH}\right]$ \\
\hline & 2 nd & $343-464$ & 436 & - & 423 & $25.80 / 22.15$ & $-\left[-\mathrm{N}\left(\mathrm{C}_{2} \mathrm{H}_{5}\right)_{2}\right]$ \\
\hline & $3 \mathrm{rd}$ & $464-595$ & 572 & - & - & $27.08 / 27.69$ & $-\left[\mathrm{C}_{6} \mathrm{H}_{4} \mathrm{~N}\right]$ \\
\hline \multirow{5}{*}[\mathrm{Co}(\mathrm{L})_{2}]{} & $1 \mathrm{st}$ & $228-271$ & 241 & 226 & 241 & $5.41 / 4.80$ & $-[2 \mathrm{OH}]$ \\
\hline & 2nd & $271-308$ & 276 & 264 & - & $2.35 / 2.12$ & $-\left[\mathrm{CH}_{3}\right]$ \\
\hline & $3 \mathrm{rd}$ & $308-347$ & 316 & 264 & - & $4.01 / 3.67$ & $-\left[\mathrm{C}_{2} \mathrm{H}_{5}\right]$ \\
\hline & 4th & $347-505$ & 408 & - & 405 & $31.80 / 31.11$ & $-\left[\mathrm{C}_{6} \mathrm{H}_{4} \mathrm{CN}, \mathrm{N}\left(\mathrm{C}_{2} \mathrm{H}_{5}\right), \mathrm{N}\left(\mathrm{C}_{2} \mathrm{H}_{5}\right)_{2}\right]$ \\
\hline & 5 th & $505-595$ & 516 & - & 522 & $5.46 / 5.79$ & $-\left[\mathrm{CH}_{3} \mathrm{CN}\right]$ \\
\hline \multirow{4}{*}[\mathrm{Ni}(\mathrm{L})_{2}]{$\cdot 0.5 \mathrm{H}_{2} \mathrm{O}$} & 1 st & $95-140$ & - & - & - & $1.45 / 1.25$ & $-\left[0.5 \mathrm{H}_{2} \mathrm{O}\right]$ \\
\hline & 2 nd & $140-304$ & 284 & - & 286 & $12.75 / 12.16$ & $-\left[\mathrm{N}\left(\mathrm{C}_{2} \mathrm{H}_{5}\right)_{2}, \mathrm{CH}_{3}\right]$ \\
\hline & $3 r d$ & $304-449$ & 368 & - & 364 & $38.94 / 38.63$ & $-\left[\mathrm{C}_{6} \mathrm{H}_{4}-\mathrm{CH}=\mathrm{N}-\mathrm{C}_{6} \mathrm{H}_{4}-\mathrm{C}=\mathrm{NOH}, \mathrm{CH}_{3} \mathrm{C}=\mathrm{NOH}\right]$ \\
\hline & 4th & $449-595$ & & & 385 & $12.68 / 12.41$ & $-\left[\mathrm{C}_{6} \mathrm{H}_{4} \mathrm{~N}\right]$ \\
\hline
\end{tabular}

respectively. These two steps exhibited as two exothermic processes with two weak and broad $\left(\mathrm{T}_{\mathrm{DTA}}\right)$ peaks at $405^{\circ} \mathrm{C}$ and $522^{\circ} \mathrm{C}$, for two steps, respectively. The most probable remaining products (theoretically calculated $52.27 \%$ ) may be assigned to $\mathrm{Co}(\mathrm{II})$ phenolate residues $\left[\mathrm{C}_{13} \mathrm{H}_{8} \mathrm{NO}-\mathrm{Co}-\mathrm{C}_{7} \mathrm{H}_{4} \mathrm{NO}\right]$ (Agata, 2018).

The first step of decomposition in TG/DTG/DTA curves of $\left[\mathrm{Ni}(\mathrm{L})_{2}\right] \cdot 0.5 \mathrm{H}_{2} \mathrm{O}$ complex, Figure 12, includes the dehydration of half-molecule of lattice water, with Obs. $1.45 \%$, Calc. $1.25 \%$ mass loss, at a temperature range of $95^{\circ} \mathrm{C}-140^{\circ} \mathrm{C}$ (Ratiram et al., 2015). In general, the dehydration of lattice water molecules in chelation compounds revealed weak or strong interaction behavior (Ratiram et al., 2013b). The second pyrolysis step in TG/DTG/DTA curves initial at $140^{\circ} \mathrm{C}-304^{\circ} \mathrm{C}$, with weak $\mathrm{T}_{\text {DTG }}$ peak at $284^{\circ} \mathrm{C}$ and very sharp and strong exothermic $\left(\mathrm{T}_{\mathrm{DTA}}\right)$ peak at $286^{\circ} \mathrm{C}$ related to decomposition of $\left[\mathrm{N}\left(\mathrm{C}_{2} \mathrm{H}_{5}\right)_{2}\right]$ and $\left[\mathrm{CH}_{3}\right]$ groups from ligand backbone (Obs. 12.75\%, Calc. 12.16\%). Third decomposition step was noticed at a temperature range of $304^{\circ} \mathrm{C}-449^{\circ} \mathrm{C}$, assigned to Obs. $38.94 \%$, Calc. $38.63 \%$ mass loss, may be assigned to decomposition of $\left[\mathrm{C}_{6} \mathrm{H}_{4}-\mathrm{CH}=\mathrm{N}-\mathrm{C}_{6} \mathrm{H}_{4}-\right.$ $\mathrm{C}=\mathrm{NOH}]$ and $\left[\mathrm{CH}_{3} \mathrm{C}=\mathrm{NOH}\right]$ parts, from ligand backbone, with weak $\mathrm{T}_{\text {DTG }}$ peak at $368^{\circ} \mathrm{C}$, and two sharp and weak exothermic $\left(\mathrm{T}_{\text {DTA }}\right)$ peaks at $364^{\circ} \mathrm{C}$ and $385^{\circ} \mathrm{C}$. The fourth decomposition step initiated at $449^{\circ} \mathrm{C}-595^{\circ} \mathrm{C}$, with no detection of peaks related to both $\mathrm{T}_{\text {DTG }}$ and $\mathrm{T}_{\text {DTA }}$. The final step assigned to Obs. $12.68 \%$, Calc. $12.41 \%$ mass loss due to consumption of $\left[\mathrm{C}_{6} \mathrm{H}_{4} \mathrm{~N}\right]$ from ligand backbone. The most probable remaining products (theoretically calculated $35.02 \%$ ) may be assigned to $\mathrm{Ni}$ (II) phenolate residues $\left[\mathrm{C}_{11} \mathrm{H}_{14} \mathrm{NNiO}_{2}\right],(\mathrm{TG}(2)-\mathrm{Cu}$-phenolate). The results of thermal decomposition steps of HL and its metal complexes reflected good thermal stability for it. The results of thermal decomposition related to $\mathrm{Co}$ (II) and $\mathrm{Ni}$ (II) complexes were in good agreement with Irving-Williams series and the order of stability was $\mathrm{Co}(\mathrm{II})<\mathrm{Ni}(\mathrm{II})$. Table 6 represents TG/ DTG/DTA data of HL and its complexes with decomposition steps and assignments. 


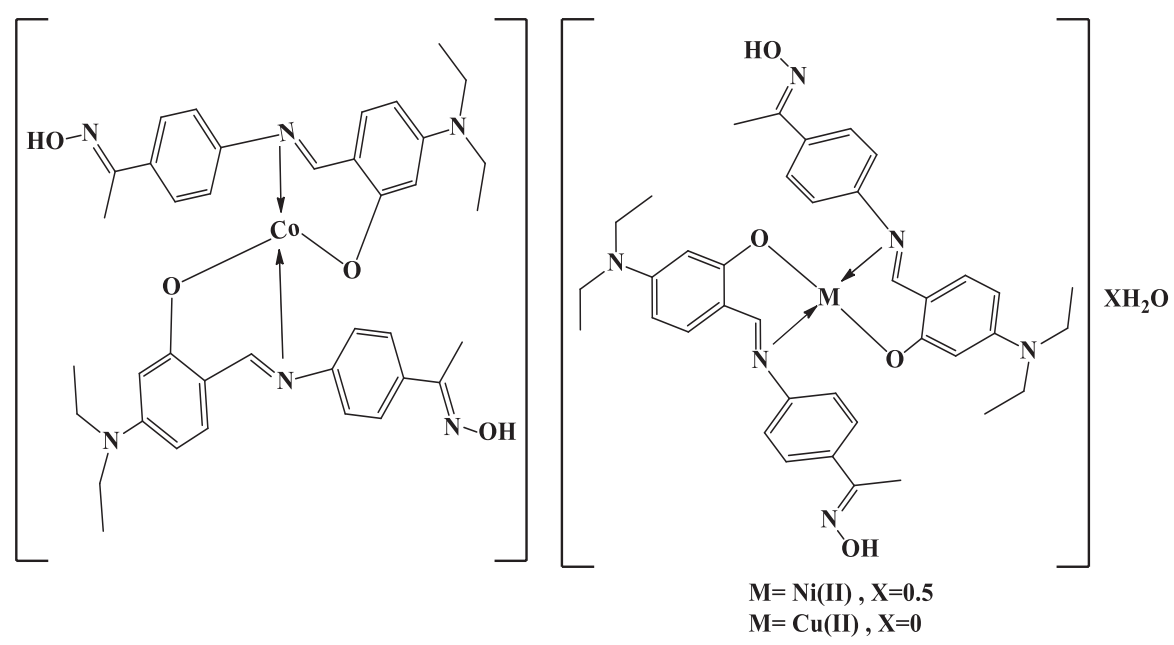

Figure 13. Proposed structures of prepared complexes.

Table 7. Inhibition Zone ( $\mathrm{mm}$ ) data of prepared compounds against selected bacterial and fungus (Candida).

\begin{tabular}{|c|c|c|c|c|c|c|c|}
\hline \multirow[b]{2}{*}{ Comp. } & \multicolumn{2}{|c|}{ Gram-positive bacteria } & \multirow[b]{2}{*}{$\begin{array}{c}\text { Klebsiella } \\
\text { spp. }\end{array}$} & \multicolumn{2}{|c|}{ Gram-negative bacteria } & \multirow[b]{2}{*}{$\begin{array}{c}\text { Pseudomonas } \\
\text { aeruginosa }\end{array}$} & \multirow{2}{*}{$\begin{array}{l}\text { Fungus } \\
\text { Candida }\end{array}$} \\
\hline & $\begin{array}{c}S . \\
\text { epidermidis }\end{array}$ & $\begin{array}{c}S . \\
\text { aureus }\end{array}$ & & E. Coli & Salmonella & & \\
\hline DMSO (C) & 0 & 0 & 0 & 0 & 0 & 0 & 0 \\
\hline $\mathrm{HL}^{\mathrm{a}}$ & 10 & 0 & 11 & 0 & 17 & 0 & 14 \\
\hline$\left[\mathrm{Co}(\mathrm{L})_{2}\right]^{\mathrm{a}}$ & 12 & 0 & 0 & 0 & 14 & 0 & 13 \\
\hline$\left[\mathrm{Ni}(\mathrm{L})_{2}\right]^{\mathrm{a}} \cdot 0 \cdot 5 \mathrm{H}_{2} \mathrm{O}$ & 14 & 0 & 0 & 0 & 13 & 0 & 14 \\
\hline$\left[\mathrm{Cu}(\mathrm{L})_{2}\right]^{\mathrm{a}}$ & 9 & 0 & 0 & 0 & 10 & 0 & 14 \\
\hline $\mathrm{HL}^{\mathrm{b}}$ & 0 & 0 & 11 & 0 & 19 & 0 & 18 \\
\hline$\left[\mathrm{Co}(\mathrm{L})_{2}\right]^{\mathrm{b}}$ & 9 & 0 & 0 & 0 & 17 & 0 & 14 \\
\hline$\left[\mathrm{Ni}(\mathrm{L})_{2}\right]^{\mathrm{b}} \cdot 0.5 \mathrm{H}_{2} \mathrm{O}$ & 13 & 0 & 0 & 0 & 11 & 0 & 16 \\
\hline$\left[\mathrm{Cu}(\mathrm{L})_{2}\right]^{\mathrm{b}}$ & 13 & 0 & 12 & 0 & 16 & 0 & 16 \\
\hline
\end{tabular}

${ }^{\mathrm{a}} 10^{-3} \mathrm{M} ;{ }^{\mathrm{b}} 10^{-4} \mathrm{M}$.

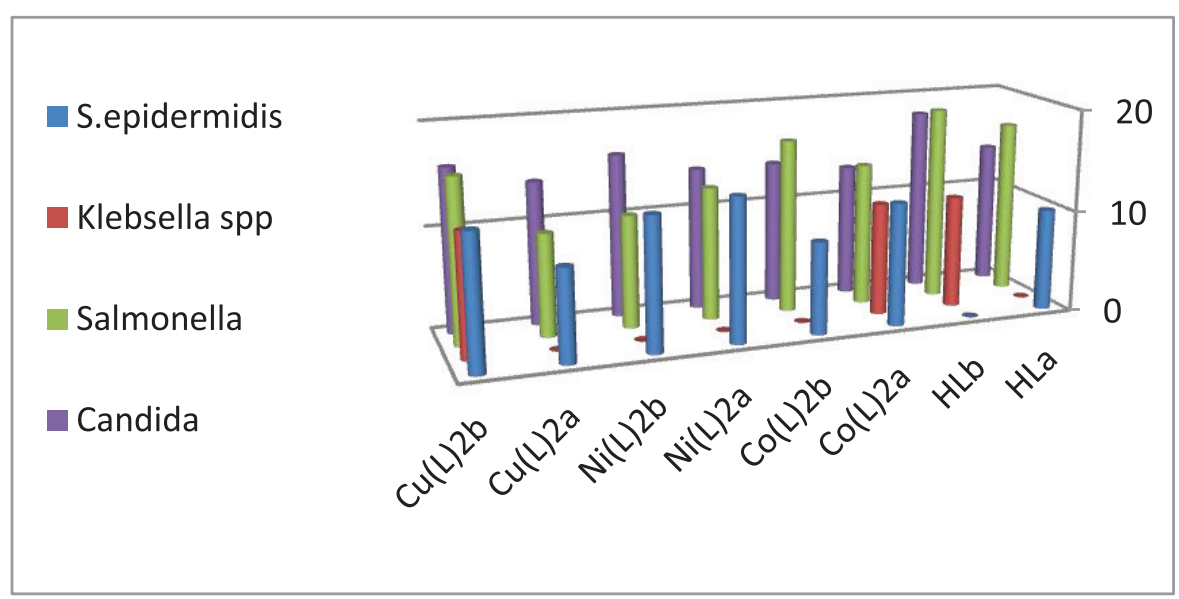

Figure 14. Graphical representation of both biological activities of HL and its complexes against three bacteria and one fungus.

\section{Molar conductivity measurements}

Molar conductance values of prepared complexes in DMSO solution were $0.6,1.2$, and $1.3 \mu \mathrm{s} . \mathrm{cm}^{-1}$ for Co(II), $\mathrm{Ni}(\mathrm{II})$, and $\mathrm{Cu}(\mathrm{II})$ complexes, respectively, indicated the nonelectrolyte nature (Shigehisa and Tatsuya, 2005) of these complexes. According to all previously mentioned analyses, we can propose structures of prepared complexes, as shown in Figure 13.

\section{BIOLOGICAL STUDIES}

Disc diffusion method has been followed to evaluate both the biological activities. Both of in vitro antibacterial and antifungal activities were tested after preparing two concentrations $\left(10^{-3} \mathrm{M}\right.$ and $\left.10^{-4} \mathrm{M}\right)$ from each compound by dissolution of the required quantities of ligand and its metal complexes in DMSO, which was used as a negative control in the experiment. The susceptibilities of certain strains of bacteria and fungal to ligand 
HL and its complexes were evaluated by measuring the inhibition zone diameter (IZ) around the holes ( $\mathrm{mm}$ ) after incubation of the plate at $37^{\circ} \mathrm{C}$ for 24 hours. There was no growth of inhibition for negative control. Among the six tested pathogenic bacteria, one gram-positive (S. epidermidis) and two gram-negative (Klebsiella spp. and Pseudomonas aeruginosa) revealed inhibitory effects. In general, ligand HL, as well as its metal complexes revealed nearly the same activity against the previously mentioned bacteria, except Klebsiella spp. At $10^{-3} \mathrm{M}$, only HL revealed inhibitory effect, while at $10^{-4} \mathrm{M}, \mathrm{HL}$ and $\mathrm{Cu}(\mathrm{L})_{2}$; HL revealed inhibitory effect against the growth of pathogenic bacteria. The inhibitory effects of solutions of prepared compounds against the growth of fungus Candida at $10^{-4} \mathrm{M}$ were larger than of concentration $10^{-3} \mathrm{M}$. Results of these biological studies are shown in Table 7. Figure 14 revealed the graphical representation of both biological activities of HL and its complexes against three bacteria and one fungus.

\section{CONCLUSION}

The newly synthesized chelation complexes of $\mathrm{Co}(\mathrm{II})$, $\mathrm{Ni}(\mathrm{II})$, and $\mathrm{Cu}(\mathrm{II})$ with the Schiff bases ligand HL contains an oxime functional group ligand that has been characterized with different analytical and spectral studies. The data of these studies showed that the complexes are mononuclear, and the ligand HL behaves as a monobasic N,O bidentate ligand. Thermal study reveals that the ligand HL and its complexes are thermally stable. Thermal stabilities related to $\mathrm{Co}(\mathrm{II})$ and $\mathrm{Ni}(\mathrm{II})$ complexes were in good agreement with Irving-Williams series and the order of stability was $\mathrm{Co}(\mathrm{II})<\mathrm{Ni}(\mathrm{II})$. Based on all have been down studies, tetrahedral geometry has been proposed for the $\mathrm{Co}$ (II) complex and square planar geometry has been proposed for $\mathrm{Ni}(\mathrm{II})$ and $\mathrm{Cu}$ (II) complexes with general formula $\left[\mathrm{M}(\mathrm{L})_{2}\right]$. The prepared compounds exhibited inhibitory effects against some of the selected pathogenic bacteria and fungus (Candida).

\section{REFERENCES}

Agata B. Synthesis, thermal behavior and some properties of CuII complexes with N,O-donor Schiff bases. J Therm Anal Calorim, 2018; 131:1221-36.

Al-Zaidi BH, Ahmed HI, Ali NN. Preparation, characterization and biological activity of new tridentate imine-oxime ligand $\left(\mathrm{H}_{2} \mathrm{~L}\right)$ and its metal complexes. Asian J Chem, 2018; 30(5):1157-64.

Al-Zaidi BH, Najat JA. Synthesis and spectral studies of $\mathrm{Cr}(\mathrm{III})$, $\mathrm{Mn}(\mathrm{II}), \mathrm{Co}(\mathrm{II}), \mathrm{Ni}(\mathrm{II}), \mathrm{Cu}(\mathrm{II})$ and $\mathrm{Cd}(\mathrm{II})$ complexes with new bidentate $(\mathrm{N}, \mathrm{O})$ Schiff base ligand bearing an oxime functional group. J Coll Basic Educ, 2014; 20(86):939-48.

Anitha S, Karthikeyan J, Nityananda SA, Lakshmisundaram R. Nickel(II) complex of p-[N,N-bis(2-chloroethyl)amino]benzaldehyde4-methyl thiosemicarbazone: synthesis, structural characterization and biological application. Polyhedron, 2013; 50:264-69.

Dong WK, Gong SS, Sun YX, Tong JF, Yao J. Structural characterization of two copper(II) complexes with oxime-type ligands. J Struct Chem, 2011; 52(5):1018-24.

Duong TQ, Jia-Sheng W, Nguyen DL, Tran D, Nguyen DD, Nguyen CB, Phan TQ. Rhodamine-derived Schiff base for the selective determination of mercuric ions in water media. Spectrochim Acta Part A, 2011; 78:753-6.

Elena P, Diana-Carolina I, Sergiu S, Codruța P, Mihaela B, Aurelian G, Tudor R. Synthesis, characterization, crystal structure and antimicrobial activity of copper(II) complexes with the Schiff base derived from 2-Hydroxy-4-Methoxybenzaldehyde. Molecules, 2015; 20:5771-92.

Erdal C, Ayşe A, Hakan Ş, Mehmet K. Some transition metal complexes of NO type Schiff base: preparation and characterization. Sci J (CSJ), 2016; 37(1):65-73.

Erdal C, Mehmet K. Studies on mononuclear chelates derived from substituted Schiff bases ligands (part 1): synthesis and characterization of a new Salicylidine-p-aminoacetophenoneoxime and its complexes with $\mathrm{Co}(\mathrm{II}), \mathrm{Ni}(\mathrm{II}), \mathrm{Cu}(\mathrm{II})$ and $\mathrm{Zn}(\mathrm{II})$. Polish J Chem, 2005; 79:959-65.

Franz AM, Roland CF, Mark S, Andres RA, Diana HT, Salah SM. Metal(II) complexes of compartmental poly nuclear Schiff bases containing phenolate and alkoxy groups. Crystals, 2016; 6(9):1-17.

Hao-Ran J, Jing L, Yin-Xia S, Jian-Qiang G, Bin Y, Na W, Li $\mathrm{X}$. Two supramolecular cobalt(II) complexes: syntheses, crystal structures, spectroscopic behaviors, and counter anion effects. Crystals, 2017; 7(247):1-15.

Hui Y, Wei Z, Qing Y, Fu-Ping H, He-Dong B, Hong L. Ni(II) complexes with Schiff base ligands: preparation, characterization, DNA protein interaction and cytotoxicity studies. Molecules, 2017; 22:1772.

Kumar VA, Sarala Y, Siddikha A, Vanitha S, Babu S, Reddy AV. Synthesis, characterization antimicrobial and antioxidant activities of 2,4-dihydroxybenzaldehyde-4-phenyl-3- thiosemicarbazone (DHBPTSC) and its $\mathrm{Pd}(\mathrm{II}), \mathrm{Ni}(\mathrm{II}) \mathrm{dppm}$ mixed ligand and $\mathrm{Cu}(\mathrm{II})$ complex having heterocyclic bases. J Appl Pharm Sci, 2018; 8(04):071-8.

Marisa SC, Clóvis AR, Valentina CM, Henrique EZ. Preparation and thermal decomposition of Copper(II), Zinc(II) and Cadimum(II) Chelate with 8-Hydroxyquinoline. Quim Nova, 1999; 22(1):41-6.

Mehdi A, Amir HM, Alireza G, Saeed D, Hamid RB. Cobalt(II), nickel(II), and zinc(II) complexes with bidentate N,N-bis(bphenylcinnamaldehyde)-1,2-diiminoethane Schiff base: synthesis and structures. Polyhedron, 2002; 21:2733-42.

Peng-Peng L, Li Z, Ji-Xing Z, Zhao-Bin Z. Crystal structure of (E)-1-(4-(((E)-4-(diethylamino)-2-hydroxybenzylidene)amino)phenyl) ethan-1-oneoxime, $\mathrm{C}_{19} \mathrm{H}_{23} \mathrm{~N}_{3} \mathrm{O}_{2}$. Z Kristallogr NCS, 2018; 233(1):13-5.

Ratiram GC, Harjeet DJ, Mangesh PG. Chelate polymer compounds with bis(bidentate) ligand: synthesis, spectral, morphological and thermal degradation studies. J Chin Adv Mater Soc, 2013a; 1(2): 121-33.

Ratiram GC, Harjeet DJ, Mangesh PG. Thermal degradation behavior of some metal chelate polymer compounds with bis(bidentate) ligand by TG/DTG/DTA. J Therm Anal Calorim, 2013b; 112:637-47.

Ratiram GC, Harjeet DJ, Ramakanth P, Nilesh VG, Mangesh PG. Synthesis, characterization and thermal degradation behavior of some coordination polymers by using TG-DTG and DTA techniques. J Saudi Chem Soc, 2015; 19:442-53.

Ratiram GC, Parvej A, Nilesh VG, Jay AT, Harjeet DJ. Thermal decomposition kinetics of some transition metal coordination polymers of fumaroyl bis (paramethoxyphenylcarbamide) using DTG/DTA techniques. Arab J Chem, 2016. https://doi.org/10.1016/j.arabjc.2016.03.008

Sakthilatha D, Rajavel R. Synthesis, characterization and biological studies of homobimetallic Schiff base $\mathrm{Cu}(\mathrm{II})$ and $\mathrm{Ni}(\mathrm{II})$ complexes. Chem Sci Trans, 2013; 2(3):711-26.

Shigehisa A, Tatsuya N. Novel thiosalamo ligand as a remarkably stable $\mathrm{N}_{2} \mathrm{~S}_{2}$ salen-type chelate and synthesis of a nickel(II) complex. Inorg Chem, 2005; 44(5):1205-07.

Senbagam R, Vijayakumar R, Rajarajan M, Balaji S, Manikandan $\mathrm{V}$, Vanangamudi G, Thirunarayanan G. Synthesis, assessment of substituent effect and antimicrobial activities of (4E)-4-(benzylideneamino)-1,2dihydro-2,3-dimethyl- 1-phenylpyrazol-5-one compounds. Karbala Int $\mathrm{J}$ Mod Sci, 2016; 2:56-62.

Swati B, Uma V. A new approach for extraction of heavy metal ion from industrial effluents by silver nanoparticles coated with $\mathrm{N}-(2-$ Hydroxybenzylidene)-2-Amino pyridine Schiff B. Asian J Sci Technol, 2017; 6(8):15945-55. 
Takjoo R, Centore R. Synthesis, X-ray structure, spectroscopic properties and DFT studies of some dithiocarbazate complexes of nickel(II). J Mol Struct, 2013; 1031:180-5.

Thavuduraj K, Antonysamy K, Ponnusamy T. Synthesis, characterization, redox and biological screening studies of copper(II), nickel(II), cobalt(II), zinc(II) and vanadium(IV) complexes derived from 1-phenyl-2,3-dimethyl-4-imino-(2 hydroxybenzylidene)-pyrozol5-( $\alpha$-imino)-indole-3- propionic acid. Int J Chem Tech Res 2012; 4(4):1571-81.

Tzu-Chien F, Hsing-Yang T, Ming-Hui L, Che-Wei C, Kew$\mathrm{Yu}$ C. Excited-state charge coupled proton transfer reaction via the dipolar functionality of salicylideneaniline. Chin Chem Lett, 2013; 24(2):145-8.

How to cite this article:

Al-Zaidi BH, Hasson MM, Ismail AH. New complexes of chelating Schiff base: Synthesis, spectral investigation, antimicrobial, and thermal behavior studies. J Appl Pharm Sci, 2019; 9(04):045-057. 